University of Nebraska - Lincoln

DigitalCommons@University of Nebraska - Lincoln

TWO-SOURCE ENERGY BALANCE MODEL TO CALCULATE E, T, AND ET: COMPARISON OF PRIESTLEY-TAYLOR AND PENMANMONTEITH FORMULATIONS AND TWO TIME SCALING METHODS

\author{
Paul D. Colaizzi \\ USDA-ARS, Paul.Colaizzi@ARS.USDA.GOV \\ Nurit Agam \\ USDA-ARS, nurit.agam@gmail.com \\ Judy A. Tolk \\ USDA-ARS \\ Steven R. Evett \\ USDA-ARS, steve.evett@ars.usda.gov \\ Terry A. Howell \\ USDA-ARS, Terry.Howell@ars.usda.gov \\ See next page for additional authors \\ Follow this and additional works at: https://digitalcommons.unl.edu/usdaarsfacpub
}

Colaizzi, Paul D.; Agam, Nurit; Tolk, Judy A.; Evett, Steven R.; Howell, Terry A.; Gowda, Prasanna H.; O'Shaughnessy, Susan A.; Kustas, William P.; and Anderson, Martha C., "TWO-SOURCE ENERGY BALANCE MODEL TO CALCULATE E, T, AND ET: COMPARISON OF PRIESTLEY-TAYLOR AND PENMAN-MONTEITH FORMULATIONS AND TWO TIME SCALING METHODS" (2014). Publications from USDA-ARS / UNL Faculty. 1818.

https://digitalcommons.unl.edu/usdaarsfacpub/1818

This Article is brought to you for free and open access by the U.S. Department of Agriculture: Agricultural Research Service, Lincoln, Nebraska at DigitalCommons@University of Nebraska - Lincoln. It has been accepted for inclusion in Publications from USDA-ARS / UNL Faculty by an authorized administrator of DigitalCommons@University of Nebraska - Lincoln. 


\section{Authors}

Paul D. Colaizzi, Nurit Agam, Judy A. Tolk, Steven R. Evett, Terry A. Howell, Prasanna H. Gowda, Susan A. O'Shaughnessy, William P. Kustas, and Martha C. Anderson 


\title{
Two-SOURCE ENERGy BALANCE MODEL TO CALCULATE E, T, AND ET: COMPARISON OF PRIESTLEY-TAYLOR AND PENMAN-MONTEITH FORMULATIONS AND TWO TIME SCALING METHODS
}

\author{
P. D. Colaizzi, N. Agam, J. A. Tolk, S. R. Evett, T. A. Howell, P. H. Gowda, \\ S. A. O’Shaughnessy, W. P. Kustas, M. C. Anderson
}

\begin{abstract}
The two-source energy balance (TSEB) model calculates the energy balance of the soil-canopy-atmosphere continuum, where transpiration is initially determined by the Priestley-Taylor equation. The TSEB was revised recently using the Penman-Monteith equation to replace the Priestley-Taylor formulation, thus better accounting for the impact of large and varying vapor pressure deficits (VPD) typical of advective, semiarid climates. This study is a comparison of the PriestleyTaylor and Penman-Monteith versions of the TSEB (termed TSEB-PT and TSEB-PM, respectively). Evaporation (E), transpiration (T), and evapotranspiration (ET) calculated by the TSEB-PT and TSEB-PM versions were compared to measurements obtained with microlysimeters, sap flow gauges, and weighing lysimeters, respectively, for fully irrigated cotton (Gossypium hirsutum L.) at Bushland, Texas. Radiometric surface temperature $\left(T_{R}\right)$ was used to calculate $E$, $T$, and ET in both TSEB versions in 15 min intervals and summed to intervals coinciding with times of measurements. In addition, a one-time-of-day $T_{R}$ measurement was used $(9: 45,11: 15,12: 45,14: 15$, or 15:45 CST), and E, T, and ET were calculated for the appropriate measurement interval (i.e., daytime, nighttime, and $24 \mathrm{~h}$ ) using the time scaling methods based on reference ET (TSC $C_{E T}$ ) and reference temperature $\left(T S C_{T E M P}\right)$. Measured average values of $E$, $T$, and ET during the study period were $0.94 \mathrm{~mm}(24 \mathrm{~h})$, $6.9 \mathrm{~mm}$ (7:00 to 22:00 CST), and $7.2 \mathrm{~mm}(24 \mathrm{~h})$, respectively. The TSEB-PT consistently overestimated $E$ and underestimated T, with RMSE/MBE of up to 2.8/1.8 mm and 4.1/-3.9 mm, respectively. In comparison, the TSEB-PM greatly reduced discrepancies between calculations and measurements, with respective RMSE/MBE for $E$ and T of only up to 1.5/0.79 mm and $1.3 / \pm 0.76 \mathrm{~mm}$, respectively. For $24 \mathrm{~h}$ ET, the TSEB-PT resulted in maximum RMSE/MBE of 3.2/-1.9 mm, and the TSEB-PM had maximum RMSE/MBE of 1.7/0.95 mm. Daytime ET model agreement was very similar for both model versions (RMSE/MBE usually $<1.1 /< \pm 1.0 \mathrm{~mm}$ ). However, the TSEB-PT consistently calculated negative nighttime ET of up to $2.0 \mathrm{~mm}$. Summed $15 \mathrm{~min}$ calculations generally had better agreement with measurements than did the TSC $C_{E T}$ or TSC $C_{T E M P}$ methods, and results did not greatly differ for TSC $C_{E T}$ or TSC $C_{T E M P}$. Both time scaling methods were not very sensitive to the $T_{R}$ measurement time used, although morning (9:45 CST) $T_{R}$ measurement times did not perform as well as the other times.
\end{abstract}

Keywords. Cotton, Energy balance model, Evaporation, Evapotranspiration, Irrigation, Remote sensing, Texas, Transpiration.

Submitted for review in September 2013 as manuscript number SW 10423; approved for publication by the Soil \& Water Division of ASABE in March 2014.

Mention of company or trade names is for description only and does not imply endorsement by the USDA. The USDA is an equal opportunity provider and employer.

The authors are Paul D. Colaizzi, ASABE Member, Research Agricultural Engineer, USDA-ARS Conservation and Production Research Laboratory (CPRL), Bushland, Texas; Nurit Agam, Professor, Blaustein Institutes for Desert Research, Ben-Gurion University of the Negev, Sede-Boqer Campus, Israel; Judy A. Tolk, Research Plant Physiologist, Steven R. Evett, ASABE Member, Research Soil Scientist, Terry A. Howell, ASABE Fellow, Research Agricultural Engineer (retired), Prasanna H. Gowda, ASABE Member, Research Agricultural Engineer, and Susan A. O'Shaughnessy, ASABE Member, Research Agricultural Engineer, USDA-ARS CPRL, Bushland, Texas; William P. Kustas, Hydrologist, and Martha C. Anderson, Research Physical Scientist, USDA-ARS Hydrology and Remote Sensing Laboratory, Beltsville, Maryland. Corresponding author: Paul D. Colaizzi, USDAARS CPRL, P.O. Drawer 10, Bushland, TX 79012-0010; phone: 806-3565763; e-mail: paul.colaizzi@ars.usda.gov. $\longrightarrow$ he two-source energy balance (TSEB) model originally described by Norman et al. (1995) and Kustas and Norman (1999) calculates estimates of sensible and latent heat fluxes of the soil and canopy components of vegetated surfaces. The latent heat flux components can be converted to evaporation (E), transpiration (T), and combined into evapotranspiration (ET). This has important applications in water resource management for natural and cultivated surfaces. Knowledge of E, $\mathrm{T}$, and ET is important for maximizing crop water productivity for irrigated and dryland crop production systems because $\mathrm{E}$ is generally considered a loss that does not contribute directly to biomass production as does $\mathrm{T}$ (Doorenbos and Kassam, 1979; Agam et al., 2012, and references therein). Therefore, effective irrigated and dryland crop management must include strategies that seek to maximize the T/ET ratio (Evett and Tolk, 2009). Consumptive use of water by vegetated surfaces is usually combined in terms of ET because measurement of the separate E and 
$\mathrm{T}$ components is extremely challenging relative to ET (Newman et al., 2006). Therefore, most TSEB studies have addressed the bulk soil-vegetation sensible and latent heat fluxes (Kalma et al., 2008; Li et al., 2009; Kustas and Anderson, 2009). However, measurement and modeling of the $\mathrm{E}$ and $\mathrm{T}$ components have increasing importance in order to maintain crop production in the face of increasing population and decreasing water resources in the world under the uncertainty imposed by climate change (Newman et al., 2006).

The TSEB requires input data that are routinely available or can be estimated with reasonable accuracy. It is a temperature gradient-resistance model driven by the directional brightness temperature of vegetated surfaces (retrieved from satellites, aircraft, or ground-based remote sensing platforms), meteorological data (solar irradiance, air temperature, relative humidity, and wind speed), basic information about the vegetated surface (canopy height, width, leaf area index, and portion of actively transpiring vegetation), and calculated soil and aerodynamic resistances. Directional brightness temperature can be converted to radiometric surface temperature by considering surface emissivities and downwelling longwave irradiance (Norman and Becker, 1995). Radiometric surface temperature can also be retrieved from longwave pyrgeometers by inverting the Stefan-Boltzmann relation (Kustas et al., 2012). Radiometric surface temperature is usually a composite of both the substrate (i.e., soil) and canopy (i.e., vegetation) components, even when measurements are available at relatively fine spatial resolution (i.e., on the order of a few meters). Because surface temperatures are usually available at only a single view angle, additional equations are required to calculate the soil and canopy temperatures, which govern sensible heat flux exchange. The TSEB uses a system of temperature gradient-resistance equations that are solved by an iterative secant procedure developed by Norman et al. (1995) in which an initial estimate of canopy latent heat flux (i.e., plant transpiration) under non-water-stressed conditions is related to the other energy components, as described below.

To calculate the initial canopy latent heat flux, Norman et al. (1995) proposed that a form of the Priestley-Taylor equation (Priestley and Taylor, 1972) be used:

$$
\mathrm{LE}_{C I}=-R_{N, C} \alpha_{P T} f_{G} \frac{\Delta}{\Delta+\gamma}
$$

where $\mathrm{LE}_{C I}$ is the initial canopy latent heat flux $\left(\mathrm{W} \mathrm{m}^{-2}\right)$, $R_{N, C}$ is the net radiation to the canopy $\left(\mathrm{W} \mathrm{m}^{-2}\right), \alpha_{P T}$ is the Priestley-Taylor parameter $\left(\alpha_{\mathrm{PT}}=\sim 1.26\right), f_{G}$ is the fraction of green vegetation $\left(f_{G}=1.0\right), \Delta$ is the slope of the saturation vapor pressure-temperature relation $\left(\mathrm{kPa}^{\circ} \mathrm{C}^{-1}\right), \gamma$ is the psychrometric constant $\left(\mathrm{kPa}^{\circ} \mathrm{C}^{-1}\right)$, and the sign convention is positive toward the canopy. The Priestley-Taylor equation is a simplification of the Penman-Monteith equation where $\alpha_{\mathrm{PT}}$ is substituted for the aerodynamic component, and $R_{N, C}$ is assumed to dominate over the aerodynamic component, which applies to daytime equilibrium evaporation conditions (i.e., non-advective, near saturated boundary layer). Although the Penman-Monteith equation had long been accepted by the ET community as preferable over other models (e.g., Allen et al., 2005), it is surmised that Norman et al. (1995) chose the Priestley-Taylor model because it avoided error introduced by uncertainties in vapor pressure deficit and bulk canopy resistance, which are required in a Penman-Monteith form. In addition, not requiring vapor pressure deficit made application of the TSEB less restrictive when there was a paucity of humidity data. Furthermore, Norman et al. (1995) argued that, based on plant physiology considerations, the primary driver of plant transpiration is net radiation to the canopy. This is because changes in vapor pressure deficit and stomatal conductance tend to compensate for each other when relative humidity is approximately $25 \%$ to $75 \%$, which applies to most midday, well-watered conditions when vegetation is transpiring. The use of equation 1 is supported by numerous TSEB studies that reported good agreement between measured and calculated daytime or $24 \mathrm{~h}$ latent heat flux or ET (e.g., Kustas and Norman, 1999; Li et al., 2005; Anderson et al., 2005; French et al., 2007; Agam et al., 2010; Colaizzi et al., 2012a; Kustas et al., 2012; Anderson et al., 2012). However, a number of studies have reported improved estimates of latent heat flux or ET when $\alpha_{P T}$ is variable and calculated as a locally calibrated empirical function of vapor pressure deficit (e.g., Jury and Tanner, 1975; Steiner et al., 1991; Agam et al., 2010) or when $\alpha_{P T}$ is increased to larger values such as $\sim 2.0$ when vapor pressure deficit exceeds approximately $4 \mathrm{kPa}$ (relative humidity below $\sim 30 \%$ ) (e.g., Kustas and Norman, 1999), which would increase $\mathrm{LE}_{C I}$ and mimic the vapor pressure deficit (i.e., aerodynamic) term in the Penman-Monteith model.

Using a Penman-Monteith form, $\mathrm{LE}_{C I}$ can also be calculated as:

$$
\mathrm{LE}_{C I}=-f_{G}\left(\frac{\Delta R_{N, C}}{\Delta+\gamma^{*}}+\frac{\rho C_{P}\left(e_{S}-e_{A}\right)}{r_{A}\left(\Delta+\gamma^{*}\right)}\right)
$$

where $\rho$ is the air density $\left(\mathrm{kg} \mathrm{m}^{-3}\right), C_{P}$ is the specific heat of air (assumed constant at $\left.1013 \mathrm{~J} \mathrm{~kg}^{-1} \mathrm{~K}^{-1}\right), \gamma^{*}=\gamma\left(1+r_{C} / r_{A}\right)$, $r_{C}$ is the bulk canopy resistance $\left(\mathrm{s} \mathrm{m}^{-1}\right), r_{A}$ is the aerodynamic resistance between the canopy and the air above the canopy $\left(\mathrm{s} \mathrm{m}^{-1}\right), e_{S}$ and $e_{A}$ are the saturation and actual vapor pressures of the air, respectively $(\mathrm{kPa})$, and all other terms are as defined previously. An increase in vapor pressure deficit ( $\mathrm{VPD}=e_{S}-e_{A}$ ) may be offset by an increase in $r_{C}$; however, Allen et al. (2006) concluded that $r_{C}$ is generally constant and recommended values of $50 \mathrm{~s} \mathrm{~m}^{-1}$ during the day and $200 \mathrm{~s} \mathrm{~m}^{-1}$ at night for a reference short crop (i.e., well-watered and full canopy). Increasing VPD while holding $r_{C}$ constant results in increasing $\mathrm{LE}_{C I}$ in equation 2, similar to increasing $\alpha_{P T}$ in equation 1 . Colaizzi et al. (2012b) tested the TSEB in a highly advective, semiarid climate for irrigated cotton. A preliminary analysis indicated that daytime ET calculated by the Priestley-Taylorbased TSEB, where $\alpha_{P T}=1.26$, was in good agreement with lysimeter measurements, which was consistent with previous studies (Anderson et al., 2012; Kustas et al., 2012). However, $\mathrm{E}$ and $\mathrm{T}$ were consistently over- and underestimated, respectively, by up to $4 \mathrm{~mm} \mathrm{~d}^{-1}$ compared 
with measurements using microlysimeters and sap flow gauges. This could not be mitigated by specifying $\alpha_{P T}$ as a locally calibrated empirical function of VPD (Jury and Tanner, 1975; Steiner et al., 1991; Agam et al., 2010) or increasing the value of $\alpha_{P T}$ (Kustas and Norman, 1999) (data not shown). Steiner et al. (1991) derived the empirical relation $\alpha_{P T}=1.0+0.26 \times \mathrm{VPD}$ for the Bushland study location by following the method of Jury and Tanner (1975). This resulted in agreement between calculated and measured ET using their version of the Priestley-Taylor equation that was nearly as good as the Penman-Monteith equation for full-cover, fully irrigated grain sorghum, where ET was measured by the same large weighing lysimeter used in the present study. However, their study did not have $\mathrm{E}$ or $\mathrm{T}$ measurements and was limited to full canopy cover. Therefore, Colaizzi et al. (2012b) modified the system of TSEB equations by replacing the Priestley-Taylor forms with the Penman-Monteith formulation, herein termed TSEB-PT and TSEB-PM, respectively. This resulted in much-improved agreement between calculated and measured $\mathrm{E}$ and $\mathrm{T}$, which included partial and full canopy cover. Because that study considered only the TSEB-PM, the present study is a followup in which the TSEB-PT and TSEB-PM are compared in calculating E, T, and ET.

An additional factor that may complicate the partitioning of $\mathrm{E}$ and $\mathrm{T}$, as well as other physical processes, is the scaling from short (i.e., instantaneous) time periods to longer (i.e., daytime or $24 \mathrm{~h}$ ) time periods, herein termed time scaling. Operationally, radiometric surface temperature measurements having moderate to fine spatial resolution are usually available at only one time of day, when a remote sensing platform passes over an area of interest. However, the time periods of interest are usually daily or longer; hence, time scaling is required. Because of their importance, a number of studies have addressed time scaling methods, the most common of which are based on the evaporative fraction, reference ET, or solar irradiance approaches (e.g., Jackson et al., 1983; Crago, 1996; Colaizzi et al., 2006; Van Niel et al., 2011, 2012; Cammalleri et al., 2012; Liu et al., 2012). Although the evaporative fraction method appears to be the most commonly used (Van Niel et al., 2011), it usually does not perform as well as methods based on reference ET (Colaizzi et al., 2006) or solar irradiance (Van Niel et al., 2012). Nearly all of these studies considered only total latent heat flux or ET due to the paucity of separate $\mathrm{E}$ and $\mathrm{T}$ measurements.

The limited frequency of surface temperature measurements also limits the frequency of energy balance model applications (i.e., one time of day), which may be a confounding factor of time scaling. Biases in input variables, model assumptions, or both, could amplify the calculated E, T, and ET errors following time scaling (in addition to errors introduced by the time scaling method itself). Some approaches where models are run at two (or more) times of day, such as the dual-temperature difference (DTD; Anderson et al., 1997; Norman et al., 2000; Kustas et al., 2012), have reduced model sensitivity to biases in input variables. Other studies involving reference ET have reported that $24 \mathrm{~h}$ sums of shorter (i.e., hourly) calculations agreed more closely with $24 \mathrm{~h}$ measurements than did calculations based on $24 \mathrm{~h}$ averages of input variables (e.g., Irmak et al., 2005). A general consensus of these studies is that calculation errors at different times of day tend to cancel when summed to longer (i.e., daily or $24 \mathrm{~h}$ ) time periods, possibly because biases in micrometeorological measurements and those in the model assumptions change during the day (e.g., Allen et al., 1998). With surface temperature typically measured at only one time of day for a given location, it is nonetheless possible to model diurnal surface temperature using the temperature scaling method of Evett (1989) and Evett et al. (1994). This method was used by Peters and Evett (2004), who reformulated it for arrays of infrared thermometers aboard center pivots, which pass over different locations of the field at a single time of day, similar to satellites. The method has been successfully used to schedule center pivot irrigations and control crop water productivity for several crops, where the data thus generated were applied to algorithms such as the time-temperature threshold and time-integrated crop water stress index (e.g., Peters and Evett, 2008; O'Shaughnessy et al., 2011, 2012). A logical extension of this temperature scaling method would be application to the TSEB, where E, T, and ET would be calculated diurnally using one-time-of-day surface temperature measurements and summed to the time period of interest.

The objectives of this study were to compare the TSEBPT and TSEB-PM and to compare two time scaling methods. The time scaling methods were based on reference ET (Colaizzi et al., 2006) and a modeled diurnal surface temperature (Peters and Evett, 2004). Each time scaling method was tested using surface temperatures measured at five different times of the day. The TSEB-PT and TSEB-PM were evaluated on the basis of calculated vs. measured E, $\mathrm{T}$, and ET.

\section{Materials ANd Methods TSEB MODEL OVERVIEW}

A brief overview of the TSEB is presented here; additional details are provided by Norman et al. (1995) and Kustas and Norman (1999) for the TSEB-PT and by Colaizzi et al. (2012b) for the TSEB-PM. The available energy is assumed equal to turbulent fluxes, where canopy heat storage and photosynthesis are assumed negligible:

$$
R_{N}+G+H+\mathrm{LE}=0
$$

where $R_{N}$ is net radiation, $G$ is soil heat flux, $H$ is sensible heat flux, and LE is latent heat flux, all in $\mathrm{W} \mathrm{m}^{-2}$, and all flux components are positive toward the canopy and soil surface. Note that the sign convention used here differs from other studies where $G, H$, and LE are positive away from the soil or canopy; maintaining a consistent sign convention for all fluxes in the present study was deemed prudent for clarity in the forthcoming discussion. The LE components are partitioned into the soil and canopy components as:

$$
\mathrm{LE}_{C}=-\left(R_{N, C}+H_{C}\right)
$$




$$
\mathrm{LE}_{S}=-\left(R_{N, S}+G+H_{S}\right)
$$

where the subscripts $C$ and $S$ refer to the canopy and soil, respectively. The net radiation components were calculated based on Campbell and Norman (1998), which included geometric view factors for row crops (Colaizzi et al., 2012b, 2012c, 2012d). Calculation of $G$ used the model of Santanello and Friedl (2003), which accounts for the phase difference between $G$ and $R_{N, S}$ during the day but assumes $G$ is a constant fraction of $R_{N, S}$ at night:

$$
\begin{gathered}
G_{D A Y}=-R_{N, S}\left\{a \cdot \cos \left[\frac{2 \pi}{b}(t+c)\right]\right\}, R_{N, S}>0 \\
G_{N I G H T}=-d R_{N, S}, R_{N, S} \leq 0
\end{gathered}
$$

where $t$ is the solar time angle (s), $a$ is the amplitude parameter, $b$ is the period, and $c$ is the phase shift, and $a=$ $0.15, b=86,400$ s (i.e., $24 \mathrm{~h}$ ), $c=10,800$ s (i.e., $3 \mathrm{~h}$ ), and $d=0.5$ (Colaizzi et al., 2012b; Evett, 2002).

Sensible heat flux components were calculated based on the series resistance formulation, where exchange of turbulent fluxes occurs between the soil and canopy through the canopy air space and the air above the canopy (Norman et al., 1995):

$$
\begin{gathered}
H_{C}=\rho C_{P} \frac{T_{A C}-T_{C}}{r_{X}} \\
H_{S}=\rho C_{P} \frac{T_{A C}-T_{S}}{r_{S}} \\
H=\rho C_{P} \frac{T_{A}-T_{A C}}{r_{A}}
\end{gathered}
$$

where $T_{C}, T_{A}, T_{S}$, and $T_{A C}$ are the temperatures of the canopy, air, soil, and air within the canopy boundary layer, respectively $(\mathrm{K}), r_{X}$ is the resistance between the canopy and canopy boundary layer $\left(\mathrm{s} \mathrm{m}^{-1}\right), r_{S}$ is the resistance to heat flux in the boundary layer immediately above the soil surface $\left(\mathrm{s} \mathrm{m}^{-1}\right)$, and all other terms are defined previously. The variable $r_{X}$ was calculated following Norman et al. (1995), and $r_{S}$ and $r_{A}$ were calculated following Kustas and Norman (1999).

Radiometric surface temperature $\left(T_{R}\right)$ was calculated from measured directional brightness temperature and related to $T_{S}$ and $T_{C}$ by assuming linear mixing of the Stephan-Boltzmann relationship between radiation and temperature:

$$
T_{R}^{4}=f_{V R} T_{C}^{4}+\left(1-f_{V R}\right) T_{S}^{4}
$$

where $f_{V R}$ is the fraction of vegetation appearing in the radiometer field of view (i.e., the vegetation view factor), which was calculated based on a geometric model where an elliptical radiometer footprint was imposed on crop rows (Colaizzi et al., 2010), and $T_{R}, T_{C}$, and $T_{S}$ are in $\mathrm{K}$.

This system of equations was solved using an iterative secant procedure, which was essentially the same for the
TSEB-PT and TSEB-PM. If the canopy is transpiring below its potential (i.e., available energy is not the limiting factor), such as from limited soil water, senesced leaves or other non-transpiring elements, or if VPD is small (below $\sim 1 \mathrm{kPa}$ ), then equations 1 or 2 do not apply, and the model solution may result in $\mathrm{LE}_{S}<0$. This would imply condensation on the soil surface; in a semiarid climate during the growing season, this is unlikely during the day and not common during the night, even for fully irrigated conditions (Agam et al., 2012). Therefore, if $\mathrm{LE}_{S}<0$ results, then $\alpha_{P T}$ is incrementally decreased (in eq. 1) or $r_{C}$ is incrementally increased (from 50 or $200 \mathrm{~s} \mathrm{~m}^{-1}$ for day and night, respectively, in eq. 2), and the secant procedure is repeated until $\mathrm{LE}_{S} \geq 0$. If $\mathrm{LE}_{S}<0$ still results when $\alpha_{P T}=0$ or $r_{C}$ reaches a maximum value (set to $1000 \mathrm{~s} \mathrm{~m}^{-1}$ ), the soil surface is assumed dry. In this case, $\mathrm{LE}_{S}$ is set to zero, resulting in $H_{S}=R_{N, S}-G$ from equation $4 \mathrm{~b}$, and the secant procedure is recalculated subject to this constraint. Reducing $\alpha_{P T}$ or increasing $r_{C}$ has the same effect as reducing $f_{G}$ in equations 1 and 2 , respectively. In the present study, attempts to reduce $f_{G}$ below 1.0 toward the end of the season when leaves were senescing did not appear to be justified because $\alpha_{P T}$ and $r_{C}$ were already being reduced or increased, respectively, and field measurements ceased before a significant portion of leaves senesced (data not shown). Therefore, $f_{G}$ was kept at 1.0 throughout the study period for both TSEB-PT and TSEB-PM. However, results from French et al. (2007), Guzinski et al. (2013), and others indicate that appropriate reduction in $f_{G}$ below 1.0 during senescent periods remains a topic in need of further investigation. In addition to requiring $\mathrm{LE}_{S} \geq 0$, the minimum value of $T_{S}$ was constrained to not falling below the air wetbulb temperature, which approximates the temperature of an evaporating soil surface (Wanjura and Upchurch, 1996). Although $\mathrm{LE}_{S}$ was constrained from being negative, this constraint was not imposed on $\mathrm{LE}_{C}$ to allow for the possibility of nighttime condensation on the canopy, which is more likely than the soil to cool below the dew point temperature (Tolk et al., 2006b).

The calculated latent heat flux components $\left(\mathrm{LE}_{S}, \mathrm{LE}_{C}\right.$, and LE) were converted to $\mathrm{E}, \mathrm{T}$, and $\mathrm{ET}$, respectively, in $\mathrm{mm}$, e.g., $\mathrm{ET}=-1000 \times 900 \times \mathrm{LE} /\left(\rho_{W} \lambda\right)$, where the minus sign coverts the sign convention to positive away from the soil surface and canopy, 1000 converts $\mathrm{m}$ to $\mathrm{mm}, 900$ converts seconds to a $15 \mathrm{~min}$ interval (or appropriate conversion for other time intervals), $\rho_{W}$ is the density of water (assumed $1,000 \mathrm{~kg} \mathrm{~m}^{-3}$ ), and $\lambda$ is the latent heat of vaporization ( $\mathrm{MJ} \mathrm{kg}^{-1}$ ): $\lambda=2.501-0.002361 T_{A}$, where $T_{A}$ is air temperature $\left({ }^{\circ} \mathrm{C}\right)$, and $\lambda=\sim 2.44 \mathrm{MJ} \mathrm{kg}^{-1}$ during the day at the study location. In the above equation, $\mathrm{E}$ and $\mathrm{T}$ are calculated by substituting $\mathrm{LE}$ with $\mathrm{LE}_{S}$ and $\mathrm{LE}_{C}$, respectively.

\section{TIME SCALING}

The time scaling method based on reference $\mathrm{ET}\left(\mathrm{TSC}_{\mathrm{ET}}\right)$ used the calculated E, T, and ET at 15 min intervals and scaled each respective component to the time duration of interest: 


$$
\begin{aligned}
& \mathrm{E}=\left(\frac{\mathrm{E}_{t}}{\mathrm{ET}_{R E F, t}}\right) \mathrm{ET}_{R E F} \\
& \mathrm{~T}=\left(\frac{\mathrm{T}_{t}}{\mathrm{ET}_{R E F, t}}\right) \mathrm{ET}_{R E F} \\
& \mathrm{ET}=\left(\frac{\mathrm{ET}_{t}}{\mathrm{ET}_{R E F, t}}\right) \mathrm{ET}_{R E F}
\end{aligned}
$$

where $\mathrm{ET}_{R E F}$ is the reference ET $(\mathrm{mm})$ of the desired time duration (e.g., daytime or $24 \mathrm{~h}$ ), and the subscript $t$ is the time of the shorter interval (e.g., $15 \mathrm{~min}$ at, say, 11:00 to 11:15). Hence, the numerator of equation 8 contains the 15 min variable, and the left side is the variable scaled to the desired time duration. Here, partitioning of ET to its $\mathrm{E}$ and $\mathrm{T}$ components is assumed constant during the day. Although Agam et al. (2012) showed that E appeared to be decoupled from atmospheric demand, which calls into question the appropriateness of this assumption and equation $8 \mathrm{a}$, this equation is the equivalent of $\mathrm{E}=\mathrm{ET}-\mathrm{T}$, because the TSEB calculates $\mathrm{ET}_{t}$ as $\mathrm{E}_{t}+\mathrm{T}_{t}$ (cf. eq. 8c). In the TSEB-PT, $\mathrm{ET}_{R E F}$ was calculated by equation 1 and converted from $\mathrm{W} \mathrm{m}$ to $\mathrm{mm}$ as described above, except that $R_{N, C}$ was replaced by $R_{N}-G$, which were calculated by the FAO 56 procedure (Allen et al., 1998). In the TSEB-PM, $\mathrm{ET}_{R E F}$ was calculated according to the ASCE Standardized Reference ET equation for short vegetation (Allen et al., 2005).

The time scaling method based on temperature scaling (TSC ${ }_{\text {TEMP }}$ ) (Peters and Evett, 2004) used a one-time-of-day $T_{R}$ measurement and scaled $T_{R}$ to diurnal values in $15 \mathrm{~min}$ increments:

$$
T_{R, t 2}=T_{E}+\frac{\left(T_{R, t 1}-T_{E}\right)\left(T_{R E F, t 2}-T_{E}\right)}{\left(T_{R E F, t 1}-T_{E}\right)}
$$

where $T_{R E F}$ is a calculated reference temperature, $T_{E}$ is the daily minimum reference temperature, $t_{1}$ is the time of the one-time-of-day $T_{R}$ measurement (e.g., the time when a thermal radiometer passes over a specific point in the field), and $t_{2}$ is any other time of day (i.e., all $15 \mathrm{~min}$ intervals over $24 \mathrm{~h}$ ). Calculated diurnal $T_{R}$ values were then used to calculate diurnal $\mathrm{E}, \mathrm{T}$, and $\mathrm{ET}$ in the TSEB. The $\mathrm{TSC}_{\mathrm{TEMP}}$ method assumes that spatial variability of canopy temperature is negligible at predawn, when $T_{E}$ is expected to occur. Peters and Evett (2004) and subsequent studies involving temperature scaling used stationary measurements of $T_{R}$ made with a thermal radiometer aimed at a crop canopy, which provided diurnal $T_{R E F}$. Since stationary, diurnal surface temperature measurements may not always be available in practice, in this study we instead calculated $T_{R E F}$ for a non-water-stressed canopy. Therefore, this approach of the $\mathrm{TSC}_{\mathrm{TEMP}}$ method has no more input data requirements than the $\mathrm{TSC}_{\mathrm{ET}}$ method. For the TSEB-PT, an expression for $T_{R E F}$ can be derived by combining equations 1,3 , and $6 \mathrm{c}$, except $T_{A C}$ is replaced with $T_{R E F}$, resulting in:

$$
T_{R E F}=T_{A}+\frac{\left(R_{N}-G\right) r_{A}}{\rho C_{P}}\left[1-\alpha_{P T} f_{G} \frac{\Delta}{\Delta+\gamma}\right]
$$

Similarly, the TSEB-PM (using eq. 2 in place of eq. 1) results in:

$$
T_{R E F}=T_{A}+\frac{\left(R_{N}-G\right) r_{A} \gamma^{*}}{\rho C_{P}\left(\Delta+\gamma^{*}\right)}-\frac{e_{S}-e_{A}}{\Delta+\gamma^{*}}
$$

which is the baseline temperature for the crop water stress index (Jackson et al., 1981). In both equations 10 and 11, $R_{N}$ and $G$ were calculated by the FAO 56 procedure (Allen at al., 1998), which only required $T_{A}$ since $T_{R}, T_{C}$, and $T_{S}$ were not initially available. However, we found that a second iteration improved agreement between measured and calculated (scaled) $T_{R}$. Here, the first calculations of $T_{R E F}$ and $T_{R}$ were used to calculate $T_{S}$ (eq. 7), and then $R_{N, C}, R_{N, S}$, and $G$ were calculated as described above for the TSEB, and $T_{R E F}$ and $T_{R}$ were recalculated. This likely resulted in more accurate energy partitioning to the canopy and soil for partial row crop cover, which would be expected to differ from FAO 56 calculations because the latter applies to full cover.

\section{DATA}

All data were obtained at the USDA-ARS Conservation and Production Research Laboratory in Bushland, Texas $\left(35^{\circ} 11^{\prime} \mathrm{N},-102^{\circ} 06^{\prime} \mathrm{W}, 1170 \mathrm{~m}\right.$ elevation m.s.l.) during the 2008 Bushland Evapotranspiration and Agricultural Remote Sensing Experiment (BEAREX'08) (Evett et al., 2012a). The climate is semi-arid with a large evaporative demand of about $2600 \mathrm{~mm}$ per year (Class A pan evaporation) and precipitation averaging $470 \mathrm{~mm}$ per year. The climate is noted for its significant regional advection, with $H$ contributing up to $60 \%$ of total ET of irrigated alfalfa (Tolk et al., 2006a). The soil is a Pullman clay loam (fine, mixed, super active, thermic torrertic Paleustolls) with slow permeability, a dense B2 layer from about 0.15 to $0.40 \mathrm{~m}$ depth, and a calcic horizon that begins at approximately the $1.1 \mathrm{~m}$ depth (USDA-NRCS, 2013).

Upland cotton (Gossypium hirsutum L.) was planted on 17 May 2008 (DOY 142). Cultural practices were similar to those used for commercial cotton production in the Southern High Plains. Planting density was 15.8 seeds $\mathrm{m}^{-2}$ on north-south raised beds that were spaced $0.76 \mathrm{~m}$ apart, and furrow dikes were installed across every interrow following crop establishment to control runoff and runon of irrigation water and rainfall (Schneider and Howell, 2000). The crop was fully irrigated (meeting $100 \%$ of crop ET) with a lateral-move sprinkler irrigation system.

ET was measured using a large monolithic lysimeter located in the center of a 4.7 ha field, calculated as the net change in mass divided by lysimeter area. The lysimeter is one of four of identical design, which are located in the centers of adjacent $\sim 4.7$ ha fields arranged in a square pattern (designated NE, NW, SE, and SW). All ET measurements used in the present study were obtained from the NE lysimeter. Each lysimeter is $3.0 \mathrm{~m} \times 3.0 \mathrm{~m}$ on the surface, $2.4 \mathrm{~m}$ deep, and calibrated to $0.04 \mathrm{~mm}$ accuracy prior to the 
growing season (Evett et al., 2012b). The change in lysimeter mass (net result of $\mathrm{E}$ and $\mathrm{T}$ minus irrigation, precipitation, and dew) was measured using a load cell (SM-50, Interface, Inc., Scottsdale, Ariz.) deployed on a cantilever beam beneath the lysimeter. Load cell mass was sampled every $6 \mathrm{~s}$, and ET was reported as 15 min averages. Lysimeter drainage was maintained using a vacuum pump system at $-10 \mathrm{kPa}$. Drained effluent was collected in tanks suspended from the lysimeter by load cells such that drainage did not change the total lysimeter mass. Drainage mass was measured using these load cells. ET measurements made during irrigation, precipitation, plant measurements, or instrument maintenance and repair were excluded from consideration herein. Additional details of the lysimeter design, management, and experimental protocols are given by Marek et al. (1988), Howell et al. (1995), and Evett et al. (2012b).

E was measured by microlysimeters installed in interrows approximately $30 \mathrm{~m}$ to the northeast of the lysimeter (fig. 1). Agam et al. (2012) and Evett et al. (1995) provide a full description of the microlysimeters and analysis of E measurements; a brief description is given here. The microlysimeters included two sets of five spaced $0.075,0.225$, $0.375,0.525$, and $0.675 \mathrm{~m}$ from the plant row. The microlysimeters were constructed with white polyvinylchloride (PVC) walls that were $8 \mathrm{~mm}$ thick and $88 \mathrm{~mm}$ deep with a $105 \mathrm{~mm}$ inside diameter and a metal bottom. These materials were selected to minimize lateral heat transfer but not impede vertical heat transfer with the surrounding soil. The metal bottom ensured that no soil was lost when the microlysimeters were weighed, and that changes in mass were due only to $\mathrm{E}$ and not drainage. Each microlysimeter was replaced with an undisturbed soil core daily and immediately after weighing at sunset. The mass of each microlysimeter was measured manually at dawn and dusk with an electronic scale, and daytime and nighttime $\mathrm{E}$ were calculated as the difference in microlysimeter mass between dawn and dusk and vice versa over 11 days. The scale was placed in

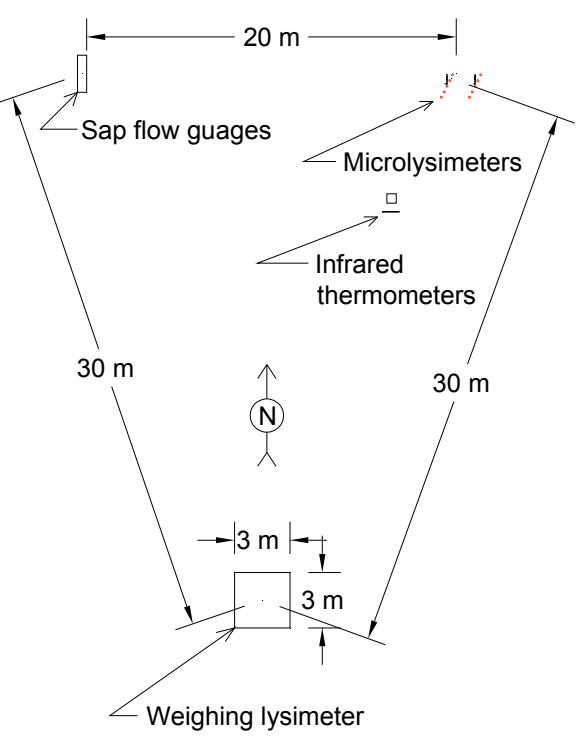

Figure 1. Relative locations of the weighing lysimeter, sap flow gauges, microlysimeters, and infrared thermometers. an enclosed box to shelter the measurements from wind, and the precision of the scale was equivalent to $0.01 \mathrm{~mm}$ of water.

T was measured by sap flow gauges (SGA- 5 and SGA9, Dynamax, Inc., Houston, Tex.) on five to ten plants located approximately $30 \mathrm{~m}$ northwest of the lysimeter and $20 \mathrm{~m}$ west of the microlysimeters (Agam et al., 2012) (fig. 1). Each gauge was installed on the plant stem approximately $0.05 \mathrm{~m}$ above the soil surface but below the first plant node. The gauges were insulated from external heat transfer and applied $\sim 0.1 \mathrm{~W}$ to the gauge strips, where sap flow was calculated based on the heat balance method (Baker and van Bavel, 1987). T was calculated as the average of sap flow reported by the gauges multiplied by the number of plants per area and reported from 7:00 to 22:00 CST.

Directional brightness temperature $\left(T_{B}\right)$ was measured by two infrared thermometers (IRT/c, Exergen Corp., Watertown, Mass.). The IRTs had an 8 to $14 \mu \mathrm{m}$ bandwidth, $5: 1$ field of view, and were mounted on stationary masts. The surface was viewed at nadir at a height of $1.5 \mathrm{~m}$ over the center of a crop row, resulting in a circular footprint with a $0.30 \mathrm{~m}$ diameter at the soil surface (Colaizzi et al., 2010). The IRTs were enclosed in a housing made of white PVC, which insulated the internal body cavity and detector to reduce the influence of longwave variability. The IRTs were located near the deployment site of the microlysimeters (approx. $30 \mathrm{~m}$ northeast of the NE lysimeter; fig. 1). $T_{B}$ was converted to $T_{R}$ by subtracting the atmospheric longwave irradiance that was estimated to be reflected into the IRT and corrected for soil and canopy emittance (Norman and Becker, 1995). Atmospheric emittance was calculated following Idso (1981). Longwave reflectance was assumed equal to the complement of bulk soil and canopy emittance, both taken as 0.98 . Soil emittance was verified over bare soil using a multiband thermal radiometer (CE 312, Cimel Electronique, Paris, France), and canopy emittance equal to 0.98 was assumed based on Idso et al. (1969) and Campbell and Norman (1998). The IRT lenses were cleaned each morning and inspected for correct viewing angle using a laser jig that was machined to fit into the lens barrel. The times of cleaning and view inspection were noted, and these were excluded from the data. $T_{B}$ was sampled every $6 \mathrm{~s}$ and reported as $15 \mathrm{~min}$ averages. The $T_{R}$ values used in the TSEB were taken as the average of data from the two IRTs, and measurements were excluded if they deviated by more than $1^{\circ} \mathrm{C}$ (Wanjura et al., 2004).

In addition to $T_{R}$, the TSEB models require measurements of incoming solar irradiance $\left(R_{S}\right)$, wind speed $(U)$, air temperature $\left(T_{A}\right)$, relative humidity $(\mathrm{RH}$, to calculate VPD), canopy width $\left(w_{C}\right)$, canopy height $\left(h_{C}\right)$, and leaf area index (LAI). $R_{S}$ was measured with a pyranometer (PSP, Eppley Laboratories, Inc., Newport, R.I.) at a micrometeorological station located $\sim 250 \mathrm{~m}$ east of the lysimeter. $T_{A}$, $\mathrm{RH}$, and $U$ were measured at a mast located immediately north of the lysimeter and $2 \mathrm{~m}$ above the soil surface. The $T_{A}$ and $\mathrm{RH}$ instruments were housed in a radiation shield (HMP45C, Vaisala, Inc., Helsinki, Finland), and $U$ was measured with a cup anemometer (Wind Sentry 03101-5, R.M. Young Co., Traverse City, Mich.). All meteorological 
variables were sampled every $6 \mathrm{~s}$ and reported as $15 \mathrm{~min}$ averages, which were subject to quality inspection following the procedures of Allen et al. (1998). Plant measurements $\left(w_{C}\right.$ and $\left.h_{C}\right)$ were recorded daily at the IRT and microlysimeter deployment sites, and approximately weekly at the lysimeter. Destructive plant samples from a $1.0 \mathrm{~m}^{2}$ area were obtained at three sites within the 4.7 ha lysimeter field (but sufficiently distant from the lysimeters and other instrumented sites) at key plant growth stages. Prior to plant sampling, $w_{C}$ and $h_{C}$ were recorded, leaf area was measured with a leaf area meter (LI-3100, LI-COR, Lincoln, Neb.), and LAI was calculated. The accuracy of the LI-COR meter was verified periodically with a $0.005 \mathrm{~m}^{2}$ standard disk. Mean values of $w_{C}, h_{C}$, and LAI were estimated by linear interpolation between sample dates by relating these variables to growing degree days of cotton. The interpolated $w_{C}$ and $h_{C}$ from the lysimeter and the interpolated mean field LAI were used as inputs in the TSEB model.

\section{Data Analysis}

Measurements of E, T, and ET were available at the different time intervals of $\sim 10$ to $14 \mathrm{~h}, 30 \mathrm{~min}$, and $15 \mathrm{~min}$, respectively, and measurement durations differed for each variable. The TSEB-PT and TSEB-PM were tested by first comparing calculated and measured $\mathrm{T}$ for a $30 \mathrm{~min}$ interval and comparing calculated - measured T and VPD for the same time interval. This is followed by discussion of the diurnal temperature and energy balance components for a single day ( $24 \mathrm{~h}$ duration) during full canopy cover (DOY 240) in $15 \mathrm{~min}$ intervals. Next, the TSEB-PT and TSEBPM were tested by comparing calculated and measured E, $\mathrm{T}$, and ET for longer durations ( $\sim 10$ to $24 \mathrm{~h})$. For E, measurement time intervals were 10 to $14 \mathrm{~h}$ (i.e., microlysimeters were weighed at dawn and dusk). For $\mathrm{T}$, measurement time intervals were $30 \mathrm{~min}$ over a $15 \mathrm{~h}$ duration (7:00 to 22:00 CST). For ET, measurement time intervals were $15 \mathrm{~min}$; this was summed to $24 \mathrm{~h}$ for daily, $\sim 14 \mathrm{~h}$ for daytime, and $\sim 10 \mathrm{~h}$ for nighttime durations. In this study, daytime is defined as when the solar zenith angle is less than $90^{\circ}$.

The appropriate duration of calculated E, T, and ET were obtained in three ways. First, the TSEB was run in 15 min intervals (i.e., corresponding to micrometeorological and $T_{R}$ data), and results were summed to the appropriate duration (i.e., 10 to $14 \mathrm{~h}$ for E, $15 \mathrm{~h}$ for T, and $24 \mathrm{~h}$ for ET). Second, the TSEB was run at one time of day and scaled by the $\mathrm{TSC}_{\mathrm{ET}}$ method (eq. 8) to produce the appropriate duration. Third, a one-time-of-day $T_{R}$ measurement was scaled diurnally by the $\mathrm{TSC}_{\mathrm{TEMP}}$ method (eq. 9), the TSEB was run using 15 min estimates of $T_{R}$, and results were summed to the appropriate duration. In order to assess the impact of time of day on the $\mathrm{TSC}_{\mathrm{ET}}$ and $\mathrm{TSC}_{\mathrm{TEMP}}$ methods, a one-time-of-day $T_{R}$ measurement was used at five times of day, including 9:45,11:15, 12:45, 14:15, and 15:45 CST. Solar noon was approximately 12:45 CST, and the overpass times of Landsat satellites were near 11:15 at the study location. The remaining times were selected arbitrarily, but a time window of $\pm 3 \mathrm{~h}$ of solar noon was considered prudent based on previous studies involving time scaling. For example, scaling factors based on the evaporative fraction, reference ET, or solar irradiance were generally constant during 3 to $4 \mathrm{~h}$ of solar noon (e.g., Crago, 1996; Van Niel et al., 2011, 2012), even during strong regional advection (Colaizzi et al., 2006). In addition, temperature scaling during this time window resulted in MAE for calculated vs. measured $T_{R}$ being minimal and nearly constant (Peters and Evett, 2004). Discrepancy between measured and calculated $T_{R}$, LE, or ET otherwise usually increased rapidly outside this time window. Furthermore, a $6 \mathrm{~h}$ interval can provide adequate coverage of fields where radiometers are deployed on center pivots, provided that the pivot rotation interval is not a factor of $24 \mathrm{~h}$ (O'Shaughnessy et al., 2011, 2012).

For each model version and time interval calculation method, agreement between calculated and measured E, T, and ET was assessed by first-order (i.e., non-squared) index of agreement (IOA), root mean squared error (RMSE), mean absolute error (MAE), and mean bias error (MBE), and the error variables were also reported as a percentage of measured means. The presence of outliers in the data is indicated by the extent that RMSE > MAE. The first-order IOA was chosen because it is less sensitive to outliers compared with squared or larger-order IOA (Legates and McCabe, 1999). The IOA varies from $-\infty$ to 1.0 , where the greater the value, the better the model agreement, and $\mathrm{IOA}=0$ indicates that the model carries no more information than does the mean of all measured values.

\section{RESULTS AND DisCUSSION \\ Plant Growth and DeVELopMent}

Measurements of E and ET that were deemed valid for model comparison were obtained over a large range of canopy cover; however, $\mathrm{T}$ measurements were obtained over a shorter period $(10 \mathrm{~d})$, resulting in a smaller canopy cover range (fig. 2). Nonetheless, $T$ measurements were obtained during partial canopy cover and rapid plant growth, which was important for testing the response of the TSEB to changing canopy cover conditions. E and ET measurements began on DOY 178 when the canopy was very sparse. E measurements were available until DOY 216, which was approximately in the middle of rapid plant growth, but ET measurements were available through peak LAI $\left(3.0 \mathrm{~m}^{2} \mathrm{~m}^{-2}\right)$ at DOY 238 and until the beginning of leaf senescence at DOY 267, when LAI declined to $1.8 \mathrm{~m}^{2} \mathrm{~m}^{-2}$. Some spatial variability in plant size was observed throughout the field during rapid development (from around DOY 180 to 240). During this time, $w_{C}$ and $h_{C}$ were larger at the lysimeter and the locations where $\mathrm{E}, \mathrm{T}$, and $T_{R}$ were measured compared with the surrounding field, which implied that LAI would also be larger at the measurement sites. There were also some differences in plant size among the lysimeter and $\mathrm{E}$ and $\mathrm{T}$ measurement sites. However, plants were more uniform following peak LAI. Since most variables were measured at the lysimeter site, the $w_{C}$ and $h_{C}$ measured there were used as input for the TSEB. Therefore, at least some discrepancy between calculated and measured E, T, and ET values could be attributed to differences in plant sizes at the different 

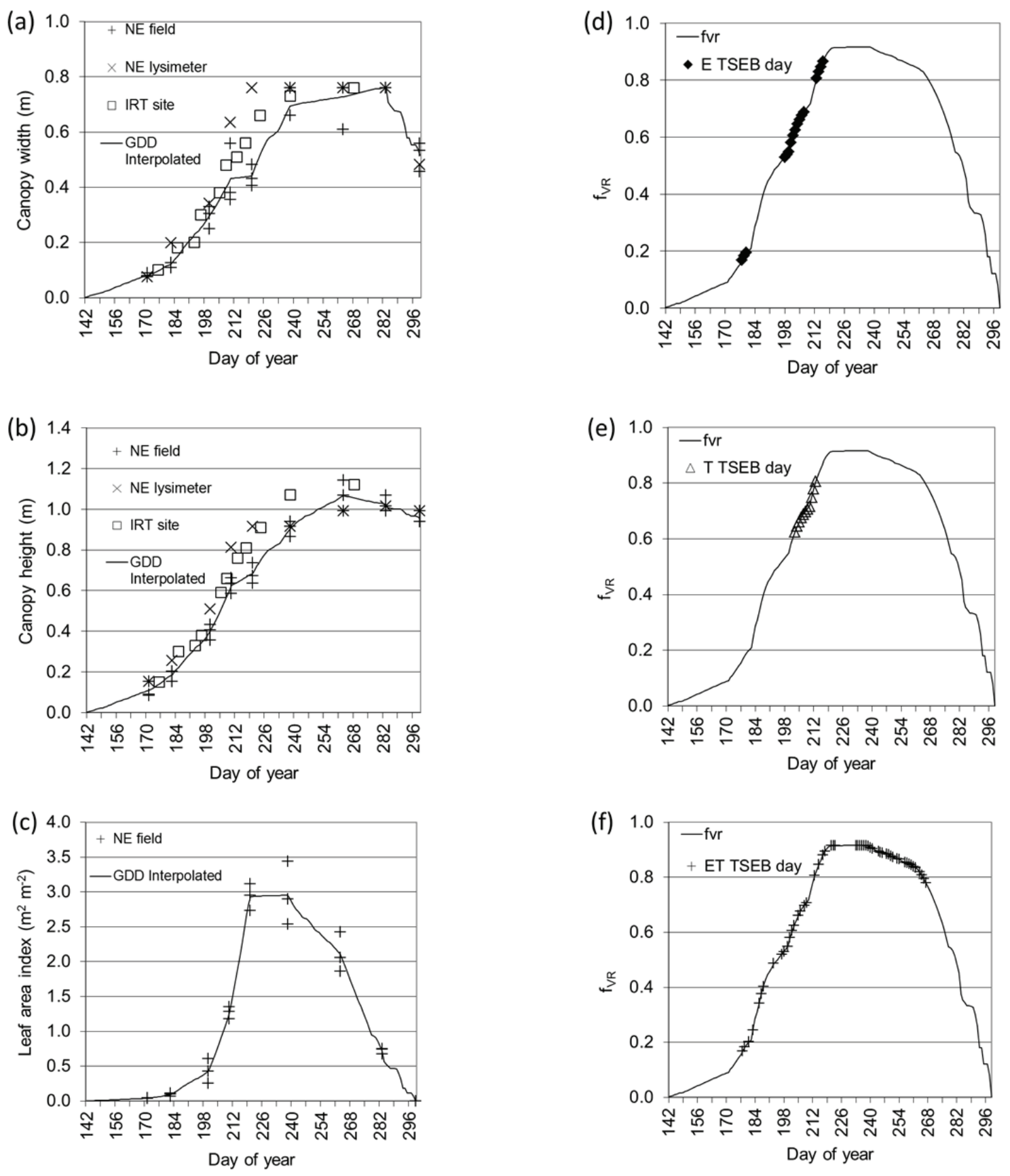

Figure 2. The 2008 cotton season with measurements of (a) canopy width, (b) canopy height, and (c) leaf area index, and vegetation view factor of IRT $\left(f_{V R}\right)$ and days of TSEB model evaluation (TSEB day) for (d) E $(n=22)$, (e) T $(n=11)$, and (f) ET ( $\left.n=53\right)($ Colaizzi et al., 2012b).

measurement sites, particularly prior to peak LAI. Attempts to adjust the LAI at the lysimeter from the field average LAI (i.e., to account for early season spatial variability) did not improve agreement between ET measured at the lysimeter and ET calculated by the TSEB model (data not shown). Additional quantification and discussion of plant spatial variability are provided by Agam et al. (2012), Alfieri et al. (2012), Colaizzi et al. (2012b), and Evett et al. (2012b). Simultaneous measurements of E, T, and ET were available during only two days without interference from irrigation, precipitation, or maintenance and repair of instruments. Therefore, data were insufficient to assess differences in $\mathrm{E}+\mathrm{T}$ and ET, which would have been useful to further explore the impact of plant spatial variability (Agam et al., 2012). Nonetheless, few if any TSEB studies included separate E, T, and ET measurements within the same crop season, as presented here.

\section{T VS. VPD}

The discrepancy between calculated and measured hourly $\mathrm{T}$ was significantly correlated to VPD for the TSEB-PT but not for the TSEB-PM $(p \leq 0.05)$ (fig. 3). For the TSEBPT, the magnitude of this discrepancy increased when measured $\mathrm{T}$ increased, and calculated minus measured $\mathrm{T}$ became more negative as VPD increased (which was expected because T and VPD are correlated). This result and 

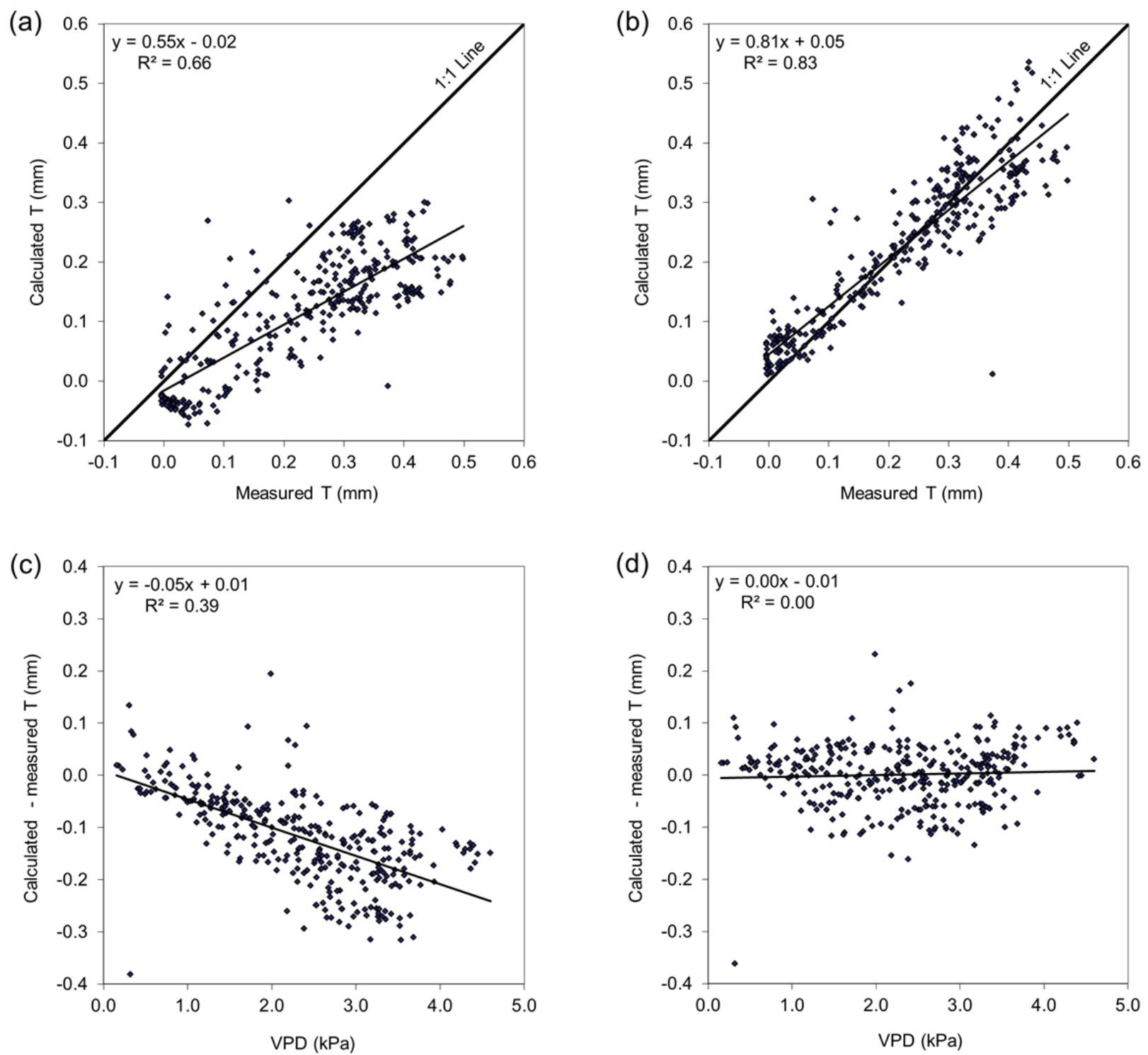

Figure 3. Calculated vs. measured T for (a) TSEB-PT and (b) TSEB-PM, and calculated - measured T (error) for (c) TSEB-PT and (d) TSEBPM ( $n=330$ for all graphs).

comparison of equations 1 and 2 imply that $\alpha_{P T}$ should be increased for large VPD. Indeed, the correlation between $\mathrm{T}$ discrepancy and VPD was reduced using the empirical function of Steiner et al. (1991), where $\alpha_{P T}=1.0+0.26 \times$ VPD, and this correlation was eliminated when $\alpha_{P T}$ was increased from 1.26 to 2.0 (data not shown). The latter result was consistent with Kustas and Norman (1999) and Agam et al. (2010), although those studies considered bulk (soil + canopy) latent heat flux. This implies that part of the TSEB-PT model discrepancy is due to underestimation of T from using an $\alpha_{P T}$ value that is too low. For $\alpha_{P T}=2.0$, regression between calculated and measured $\mathrm{T}$ resulted in $y=$ $1.01 x-0.032$ and $r^{2}=0.67$ (significant at $\mathrm{p} \leq 0.05$ ); regression between calculated - measured T and VPD resulted in $y=-0.024 x+0.026$ and $\mathrm{r}^{2}=0.055$ (not significant at $\mathrm{p} \leq$ 0.05; data not shown). As discussed previously, however, variable or larger $\alpha_{P T}$ values did not mitigate discrepancies between calculated and measured $\mathrm{E}$ and $\mathrm{T}$. Therefore, the results did not support using values other than $\alpha_{P T}=1.26$ in the present study.

\section{DiURNAL ENERGY BALANCE}

The diurnal temperature and energy flux components were calculated for the TSEB-PT and TSEB-PM on DOY 240 (fig. 4). Canopy cover was complete, where $h_{C}=$ $0.92 \mathrm{~m}$ and LAI $=2.8 \mathrm{~m}^{2} \mathrm{~m}^{-2}$ (near the average seasonal maximum of $3.0 \mathrm{~m}^{2} \mathrm{~m}^{-2}$ ), and advected $H$ contributed to LE during the afternoon. Daytime and nighttime ET measured by the lysimeter was 8.1 and $0.53 \mathrm{~mm}$, respectively. The respective daytime and nighttime ET values calculated by the TSEB-PT were 7.3 and $-0.21 \mathrm{~mm}$, and these values were 8.2 and $0.65 \mathrm{~mm}$ for the TSEB-PM. Hence, in this example, the TSEB-PT resulted in negative nighttime ET (positive nighttime LE), but the TSEB-PM resulted in positive ET (negative LE) at all times. Since canopy cover was full, the calculated $T_{C}$ and measured $T_{R}$ values would be 
(a) -Tac …... Tr - - Tc $\rightarrow$ Ts $\square$ Ta

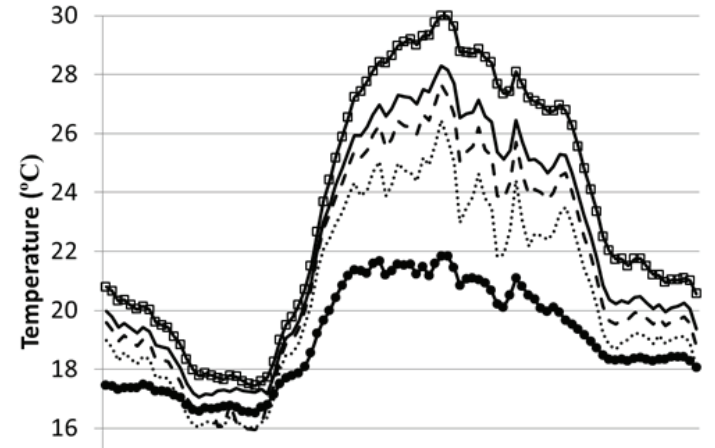

(c)

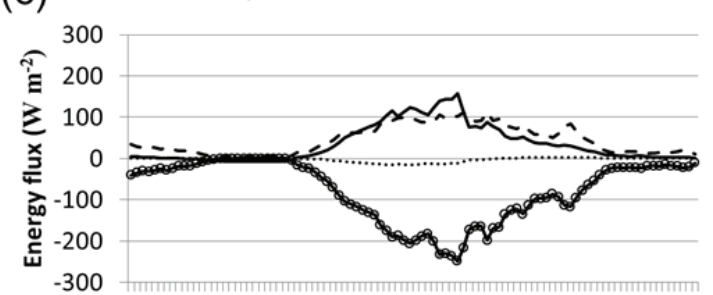

(e)

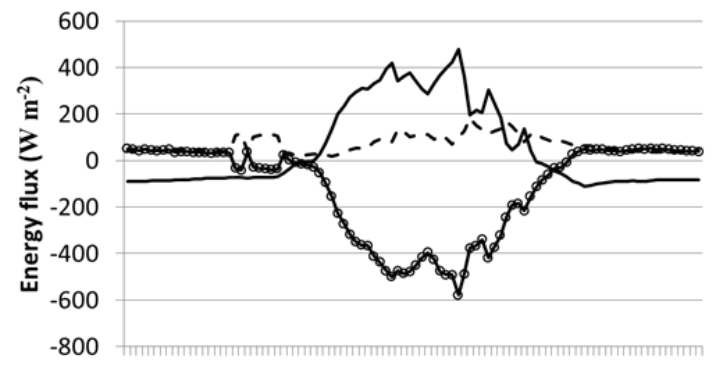

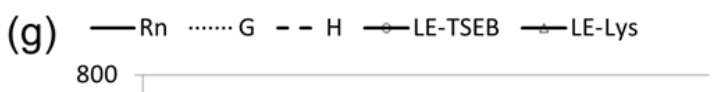

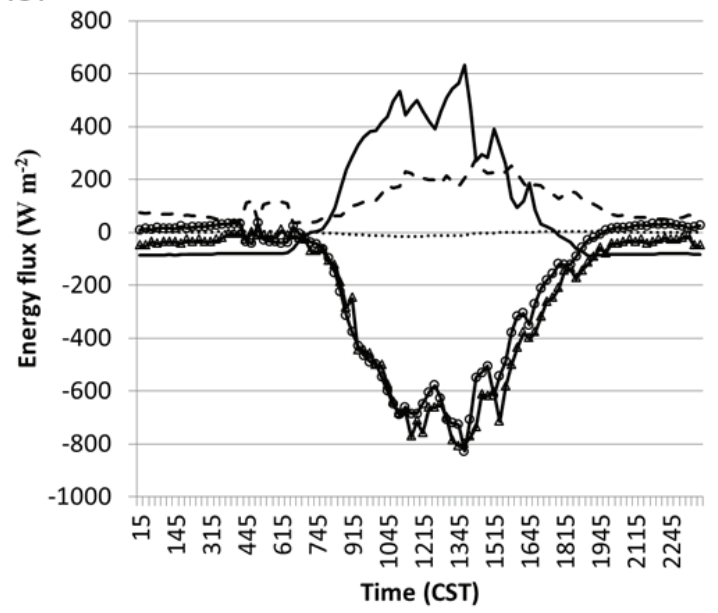

(b) -Tac ….. Tr - - Tc $\rightarrow$ Ts $\rightarrow$ Ta

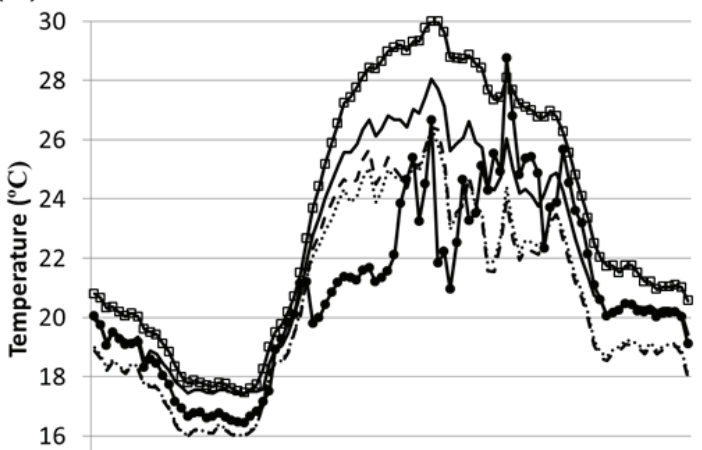

(d)

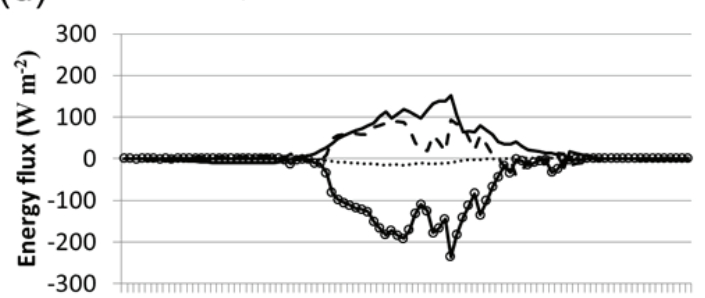

(f)

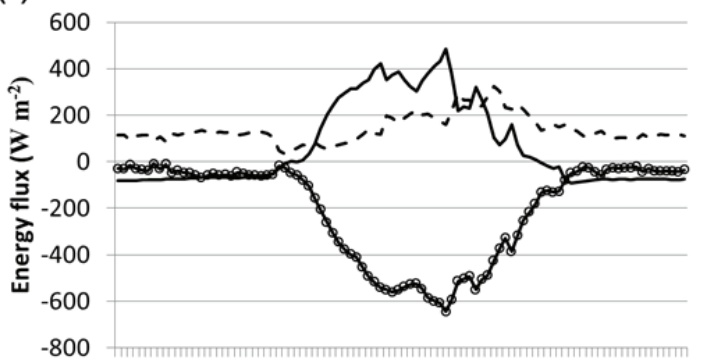

(h) $\longrightarrow \mathrm{Rn} \cdots \cdots \cdot \mathrm{G}-\mathrm{H} \longrightarrow$ LE-TSEB $\longrightarrow$ LE-Lys

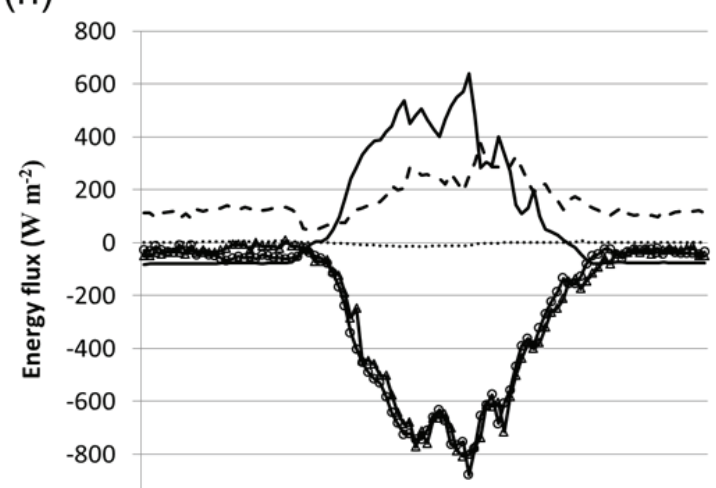

$-1000$

Figure 4. Diurnal temperatures and energy balance on DOY 240 for (a) TSEB-PT temperatures, (b) TSEB-PM temperatures, (c) TSEB-PT soil energy balance, (d) TSEB-PM soil energy balance, (e) TSEB-PT canopy energy balance, (f) TSEB-PM canopy energy balance, (g) TSEB-PT soil + canopy energy balance, and (h) TSEB-PM soil + canopy energy balance.

expected to be nearly equal throughout the day (Colaizzi et al., 2012b). However, $T_{C}>T_{R}$ by up to $\sim 2^{\circ} \mathrm{C}$ throughout the $24 \mathrm{~h}$ period for the TSEB-PT (fig. $4 \mathrm{a}$ ). In contrast, $T_{C}$ and $T_{R}$ were nearly equal for the TSEB-PM (except in the morning, when differences were $<0.5^{\circ} \mathrm{C}$ ) (fig. $4 \mathrm{~b}$ ). Hence, it appears that the TSEB-PT consistently overestimated final calculated $T_{C}$. In both versions, $T_{A C}>T_{C}$ at all times, except during the period of rapid heating about $2 \mathrm{~h}$ following sunrise, when they were nearly equal. Therefore, $H_{C}$ was always positive for both versions. At night, $R_{N, C}$ was 75 to $-100 \mathrm{~W} \mathrm{~m}^{-2}$ for both versions. The TSEB-PT $H_{C}$ was about 25 to $50 \mathrm{~W} \mathrm{~m}^{-2}$, resulting in positive $\mathrm{LE}_{C}$ up to $50 \mathrm{~W}$ $\mathrm{m}^{-2}$ (fig. $4 \mathrm{e}$ and eq. $4 \mathrm{a}$ ). Since the TSEB-PM $T_{C}$ was nearly equal to $T_{R}$ and $\left(T_{A C}-T_{C}\right)$ was larger compared with the 
TSEB-PT $\left(T_{A C}-T_{C}\right)$, the TSEB-PM $H_{C}$ was larger (approx. 100 to $125 \mathrm{~W} \mathrm{~m}^{-2}$ ), always resulting in negative $\mathrm{LE}_{C}$ at night (fig. $4 \mathrm{f}$ and eq. 4a). Since $\mathrm{LE}_{S}$ was constrained from being positive (figs. $4 \mathrm{c}$ and $4 \mathrm{~d}$ ), LE was usually equal to $\mathrm{LE}_{C}$ (figs. $4 \mathrm{~g}$ and $4 \mathrm{~h}$ ).

In this example, the differences in $\mathrm{E}$ and $\mathrm{T}$ partitioning between the TSEB-PT and TSEB-PM can be surmised by considering qualitative differences in daytime $\mathrm{LE}_{S}$ and $\mathrm{LE}_{C}$ (fig. 4). The TSEB-PT resulted in greater $T_{C}$, less $\left(T_{A C}-\right.$ $T_{C}$ ), and less $H_{C}$ compared with the TSEB-PM. Since available energy was approximately the same and $H_{C}$ was always positive for both versions, $\mathrm{LE}_{C}$ was greater for the TSEB-PM (fig. 4f) compared with the TSEB-PT (fig. 4g). Furthermore, the larger TSEB-PT $T_{C}$ resulted in smaller $T_{S}$ (fig. 4a) compared with the TSEB-PM (fig. 4b) (cf. eq. 7). Since $T_{A C}>T_{S}$ for both versions, $H_{S}$ and $\mathrm{LE}_{S}$ were larger for the former (fig. 4c) compared with the latter (fig. 4d) version. The TSEB-PT final $24 \mathrm{~h}$ calculated $\mathrm{E}$ and $\mathrm{T}$ were 2.8 and $4.3 \mathrm{~mm}$, respectively, and the TSEB-PM final $24 \mathrm{~h}$ calculated $\mathrm{E}$ and $\mathrm{T}$ were 1.5 and $7.3 \mathrm{~mm}$, respectively. Although neither $\mathrm{E}$ nor $\mathrm{T}$ measurements were available on DOY 240, this implies that the overestimates of $E$ and underestimates of $\mathrm{T}$ were largely related to overestimates of $T_{C}$ and underestimates of $\left(T_{A C}-T_{C}\right)$ for the TSEB-PT. As discussed previously, discrepancies between measured and calculated T were correlated to VPD, which further implies that overestimates of $T_{C}$ result because the TSEB-PT does not directly account for VPD, as the TSEB-PM does.

\section{E, T, AND ET}

Statistical parameters of agreement were compiled for calculated vs. measured E (table 1), T (table 2), and $24 \mathrm{~h}$ ET (table 3 ). For each variable, the TSEB-PM consistently resulted in better agreement between calculated and measured data compared with the TSEB-PT in terms of IOA, RMSE, MAE, and MBE. In most cases, RMSE was $6 \%$ to
$50 \%$ greater than MAE, indicating that the data were relatively free of outliers. The TSEB-PT consistently overestimated E (table 1), underestimated T (table 2), and underestimated ET (table 3) compared with measurements, regardless of how the time duration of each variable was calculated. This included 15 min sums (fig. 5), time scaling based on $\mathrm{TSC}_{\mathrm{ET}}$ (fig. 6), and time scaling based on $\mathrm{TSC}_{\mathrm{TEMP}}$ (fig. 7). The large range of measured ET was due to variations in atmospheric demand and the large range of canopy development. The scatter plots of $\mathrm{TSC}_{\mathrm{ET}}$ and $\mathrm{TSC}_{\mathrm{TEMP}}$ time scaling (figs. 6 and 7, respectively) used a one-time-of-day TR measurement at 11:15 CST, which is the approximate overpass time of a Landsat satellite. For the TSEB-PT, the MBE of E was 1.2 to $1.8 \mathrm{~mm}$ (table 1), the MBE of T was 2.9 to $-3.9 \mathrm{~mm}$ (table 2), and the MBE of ET was -0.50 to $1.9 \mathrm{~mm}$ (table 3). The TSEB-PM also overestimated E (table 1) and ET (table 3), but T was mostly underestimated using $\mathrm{TSC}_{\mathrm{ET}}$ and overestimated using $\mathrm{TSC}_{\mathrm{TEMP}}$ time scaling (table 2). For the TSEB-PM, the MBE of E was 0.05 to $0.79 \mathrm{~mm}$ (table 1), the MBE of $\mathrm{T}$ was -0.76 to $0.76 \mathrm{~mm}$ (table 2), and the MBE of ET was -0.06 to $0.95 \mathrm{~mm}$ (table 3). Differences in TSEB-PT vs. TSEB-PM performance for ET did not differ greatly, in sharp contrast to E and T (figs. 5, 6, and 7).

\section{TIME SCALING}

The two time scaling methods analyzed here $\left(\mathrm{TSC}_{\mathrm{ET}}\right.$ and $\mathrm{TSC}_{\mathrm{TEMP}}$ ) did not have large impacts on agreement between calculated and measured E (table 1), T (table 2), or ET (table 3), although some differences occurred. For the TSEB$\mathrm{PM}, \mathrm{TSC}_{\mathrm{TEMP}}$ had a slight advantage over $\mathrm{TSC}_{\mathrm{ET}}$ for $\mathrm{E}$ (table 1) and T (table 2), but vice versa for ET (table 3). Model agreement with measured $\mathrm{E}$ and $\mathrm{T}$ using both scaling methods did not differ greatly from summed $\mathrm{E}$ and $\mathrm{T}$. In some cases, both $\mathrm{TSC}_{\mathrm{ET}}$ and $\mathrm{TSC}_{\mathrm{TEMP}}$ resulted in even better model agreement with measurements compared with the

Table 1. Statistical parameters of agreement for calculated vs. measured daytime (dawn to dusk) and nighttime (dusk to dawn) $E(n=22)$. Figures 5, 6, and 7 show scatter plots.

\begin{tabular}{|c|c|c|c|c|c|c|c|c|c|c|c|c|c|}
\hline \multirow[b]{3}{*}{ Time } & \multirow{3}{*}{$\begin{array}{c}\text { Model } \\
\text { Version }\end{array}$} & \multirow{3}{*}{$\begin{array}{c}\text { Time } \\
\text { Scaling } \\
\text { Method }\end{array}$} & \multicolumn{2}{|c|}{ Measured E } & \multicolumn{2}{|c|}{ Calculated E } & \multirow[b]{3}{*}{ IOA } & \multirow{2}{*}{\multicolumn{2}{|c|}{ RMSE }} & \multirow{2}{*}{\multicolumn{2}{|c|}{ MAE }} & \multirow{2}{*}{\multicolumn{2}{|c|}{ MBE }} \\
\hline & & & \multirow{2}{*}{$\begin{array}{l}\text { Avg. } \\
(\mathrm{mm})\end{array}$} & \multirow{2}{*}{$\begin{array}{c}\mathrm{SD} \\
(\mathrm{mm})\end{array}$} & \multirow{2}{*}{$\begin{array}{l}\text { Avg. } \\
(\mathrm{mm})\end{array}$} & \multirow{2}{*}{$\begin{array}{c}\mathrm{SD} \\
(\mathrm{mm})\end{array}$} & & & & & & & \\
\hline & & & & & & & & $(\mathrm{mm})$ & $(\%)$ & $(\mathrm{mm})$ & $(\%)$ & (mm) & $(\%)$ \\
\hline \multirow{2}{*}{ Summed } & TSEB-PT & None & 0.94 & 0.90 & 2.7 & 2.6 & 0.45 & 2.6 & 273 & 1.8 & 188 & 1.7 & 186 \\
\hline & TSEB-PM & None & 0.94 & 0.90 & 1.2 & 1.3 & 0.75 & 0.7 & 76 & 0.5 & 54 & 0.23 & 25 \\
\hline \multirow[t]{4}{*}{$9: 45$} & TSEB-PT & $\mathrm{TSC}_{\mathrm{ET}}$ & 0.94 & 0.90 & 2.2 & 2.6 & 0.50 & 2.3 & 242 & 1.6 & 172 & 1.3 & 136 \\
\hline & TSEB-PT & $\mathrm{TSC}_{\mathrm{TEMP}}$ & 0.94 & 0.90 & 2.8 & 2.9 & 0.45 & 2.8 & 298 & 1.9 & 202 & 1.8 & 196 \\
\hline & TSEB-PM & $\mathrm{TSC}_{\mathrm{ET}}$ & 0.94 & 0.90 & 1.7 & 1.7 & 0.61 & 1.5 & 156 & 0.9 & 96 & 0.8 & 82 \\
\hline & TSEB-PM & $\mathrm{TSC}_{\text {TEMP }}$ & 0.94 & 0.90 & 1.6 & 1.7 & 0.65 & 1.2 & 133 & 0.8 & 90 & 0.7 & 71 \\
\hline \multirow[t]{4}{*}{$11: 15$} & TSEB-PT & $\mathrm{TSC}_{\mathrm{ET}}$ & 0.94 & 0.90 & 2.1 & 2.5 & 0.52 & 2.1 & 224 & 1.5 & 159 & 1.2 & 125 \\
\hline & TSEB-PT & $\mathrm{TSC}_{\mathrm{TEMP}}$ & 0.94 & 0.90 & 2.5 & 2.6 & 0.49 & 2.4 & 260 & 1.6 & 173 & 1.5 & 164 \\
\hline & TSEB-PM & $\mathrm{TSC}_{\mathrm{ET}}$ & 0.94 & 0.90 & 1.7 & 1.7 & 0.63 & 1.4 & 149 & 0.9 & 91 & 0.8 & 84 \\
\hline & TSEB-PM & $\mathrm{TSC}_{\text {TEMP }}$ & 0.94 & 0.90 & 1.4 & 1.5 & 0.71 & 1.0 & 104 & 0.6 & 68 & 0.5 & 48 \\
\hline \multirow[t]{4}{*}{$12: 45$} & TSEB-PT & $\mathrm{TSC}_{\mathrm{ET}}$ & 0.94 & 0.90 & 2.2 & 2.6 & 0.51 & 2.2 & 234 & 1.6 & 169 & 1.2 & 131 \\
\hline & TSEB-PT & $\mathrm{TSC}_{\text {TEMP }}$ & 0.94 & 0.90 & 2.3 & 2.5 & 0.49 & 2.3 & 241 & 1.5 & 163 & 1.3 & 144 \\
\hline & TSEB-PM & $\mathrm{TSC}_{\mathrm{ET}}$ & 0.94 & 0.90 & 1.7 & 1.7 & 0.62 & 1.3 & 140 & 0.9 & 93 & 0.7 & 80 \\
\hline & TSEB-PM & $\mathrm{TSC}_{\mathrm{TEMP}}$ & 0.94 & 0.90 & 1.2 & 1.4 & 0.72 & 0.8 & 91 & 0.6 & 62 & 0.3 & 28 \\
\hline \multirow[t]{4}{*}{$14: 15$} & TSEB-PT & $\mathrm{TSC}_{\mathrm{ET}}$ & 0.94 & 0.90 & 2.3 & 2.8 & 0.48 & 2.5 & 264 & 1.8 & 188 & 1.4 & 150 \\
\hline & TSEB-PT & $\mathrm{TSC}_{\text {TEMP }}$ & 0.94 & 0.90 & 2.3 & 2.6 & 0.52 & 2.3 & 245 & 1.4 & 154 & 1.4 & 145 \\
\hline & TSEB-PM & $\mathrm{TSC}_{\mathrm{ET}}$ & 0.94 & 0.90 & 1.6 & 1.8 & 0.63 & 1.3 & 143 & 0.8 & 88 & 0.7 & 75 \\
\hline & TSEB-PM & $\mathrm{TSC}_{\text {TEMP }}$ & 0.94 & 0.90 & 1.1 & 1.3 & 0.75 & 0.7 & 78 & 0.5 & 51 & 0.2 & 17 \\
\hline \multirow[t]{4}{*}{$15: 45$} & TSEB-PT & $\mathrm{TSC}_{\mathrm{ET}}$ & 0.94 & 0.90 & 2.5 & 3.0 & 0.46 & 2.7 & 287 & 1.9 & 206 & 1.5 & 163 \\
\hline & TSEB-PT & $\mathrm{TSC}_{\mathrm{TEMP}}$ & 0.94 & 0.90 & 2.5 & 2.6 & 0.50 & 2.4 & 254 & 1.6 & 171 & 1.5 & 164 \\
\hline & TSEB-PM & $\mathrm{TSC}_{\mathrm{ET}}$ & 0.94 & 0.90 & 1.2 & 1.4 & 0.67 & 1.0 & 103 & 0.6 & 69 & 0.3 & 31 \\
\hline & TSEB-PM & $\mathrm{TSC}_{\mathrm{TEMP}}$ & 0.94 & 0.90 & 1.0 & 1.2 & 0.78 & 0.6 & 66 & 0.4 & 43 & 0.0 & 5 \\
\hline
\end{tabular}


Table 2. Statistical parameters of agreement for calculated vs. measured daytime and evening (7:00 to 22:00 CST) T ( $n=11)$. Figures 5, 6, and 7 show scatter plots.

\begin{tabular}{|c|c|c|c|c|c|c|c|c|c|c|c|c|c|}
\hline \multirow[b]{3}{*}{ Time } & \multirow{3}{*}{$\begin{array}{c}\text { Model } \\
\text { Version }\end{array}$} & \multirow{3}{*}{$\begin{array}{c}\text { Time } \\
\text { Scaling } \\
\text { Method }\end{array}$} & \multicolumn{2}{|c|}{ Measured T } & \multicolumn{2}{|c|}{ Calculated T } & \multirow[b]{3}{*}{ IOA } & \multirow{2}{*}{\multicolumn{2}{|c|}{ RMSE }} & \multirow{2}{*}{\multicolumn{2}{|c|}{ MAE }} & \multirow{2}{*}{\multicolumn{2}{|c|}{ MBE }} \\
\hline & & & \multirow{2}{*}{$\begin{array}{l}\text { Avg. } \\
(\mathrm{mm})\end{array}$} & \multirow{2}{*}{$\begin{array}{c}\mathrm{SD} \\
(\mathrm{mm})\end{array}$} & \multirow{2}{*}{$\begin{array}{l}\text { Avg. } \\
(\mathrm{mm})\end{array}$} & \multirow{2}{*}{$\begin{array}{c}\mathrm{SD} \\
(\mathrm{mm})\end{array}$} & & & & & & & \\
\hline & & & & & & & & $(\mathrm{mm})$ & $(\%)$ & $(\mathrm{mm})$ & $(\%)$ & $(\mathrm{mm})$ & $(\%)$ \\
\hline \multirow[t]{2}{*}{ Summed } & TSEB-PT & None & 6.9 & 1.0 & 3.3 & 0.7 & 0.20 & 3.8 & 55 & 3.5 & 51 & -3.5 & -51 \\
\hline & TSEB-PM & None & 6.9 & 1.0 & 6.9 & 0.8 & 0.48 & 0.9 & 13 & 0.7 & 10 & 0.0 & 1 \\
\hline \multirow[t]{4}{*}{$9: 45$} & TSEB-PT & $\mathrm{TSC}_{\mathrm{ET}}$ & 6.9 & 1.0 & 4.0 & 0.8 & 0.22 & 3.2 & 47 & 3.0 & 43 & -2.9 & -43 \\
\hline & TSEB-PT & $\mathrm{TSC}_{\text {TEMP }}$ & 6.9 & 1.0 & 3.3 & 0.7 & 0.19 & 3.8 & 56 & 3.6 & 52 & -3.6 & -52 \\
\hline & TSEB-PM & $\mathrm{TSC}_{\mathrm{ET}}$ & 6.9 & 1.0 & 6.8 & 1.2 & 0.60 & 0.9 & 13 & 0.7 & 10 & -0.1 & -1 \\
\hline & TSEB-PM & $\mathrm{TSC}_{\text {TEMP }}$ & 6.9 & 1.0 & 7.2 & 0.9 & 0.57 & 0.9 & 13 & 0.7 & 10 & 0.4 & 5 \\
\hline \multirow[t]{4}{*}{$11: 15$} & TSEB-PT & $\mathrm{TSC}_{\mathrm{ET}}$ & 6.9 & 1.0 & 3.3 & 0.8 & 0.19 & 3.9 & 56 & 3.6 & 52 & -3.6 & -52 \\
\hline & TSEB-PT & $\mathrm{TSC}_{\mathrm{TEMP}}$ & 6.9 & 1.0 & 3.3 & 0.6 & 0.19 & 3.8 & 55 & 3.6 & 52 & -3.6 & -52 \\
\hline & TSEB-PM & $\mathrm{TSC}_{\mathrm{ET}}$ & 6.9 & 1.0 & 6.1 & 1.1 & 0.48 & 1.2 & 17 & 1.0 & 15 & -0.8 & -11 \\
\hline & TSEB-PM & $\mathrm{TSC}_{\mathrm{TEMP}}$ & 6.9 & 1.0 & 7.3 & 0.9 & 0.56 & 0.9 & 13 & 0.7 & 10 & 0.4 & 5 \\
\hline \multirow[t]{4}{*}{$12: 45$} & TSEB-PT & $\mathrm{TSC}_{\mathrm{ET}}$ & 6.9 & 1.0 & 3.0 & 0.7 & 0.18 & 4.1 & 60 & 3.9 & 57 & -3.9 & -57 \\
\hline & TSEB-PT & $\mathrm{TSC}_{\text {TEMP }}$ & 6.9 & 1.0 & 3.3 & 0.6 & 0.20 & 3.8 & 55 & 3.6 & 52 & -3.6 & -52 \\
\hline & TSEB-PM & $\mathrm{TSC}_{\mathrm{ET}}$ & 6.9 & 1.0 & 6.2 & 1.1 & 0.42 & 1.2 & 18 & 1.1 & 16 & -0.7 & -10 \\
\hline & TSEB-PM & $\mathrm{TSC}_{\text {TEMP }}$ & 6.9 & 1.0 & 7.2 & 0.8 & 0.55 & 0.8 & 12 & 0.7 & 10 & 0.3 & 4 \\
\hline \multirow[t]{4}{*}{$14: 15$} & TSEB-PT & $\mathrm{TSC}_{\mathrm{ET}}$ & 6.9 & 1.0 & 3.1 & 0.7 & 0.19 & 4.0 & 58 & 3.8 & 55 & -3.8 & -55 \\
\hline & TSEB-PT & $\mathrm{TSC}_{\text {TEMP }}$ & 6.9 & 1.0 & 3.3 & 0.6 & 0.20 & 3.8 & 55 & 3.5 & 51 & -3.5 & -51 \\
\hline & TSEB-PM & $\mathrm{TSC}_{\mathrm{ET}}$ & 6.9 & 1.0 & 6.9 & 1.1 & 0.54 & 1.0 & 14 & 0.8 & 12 & 0.0 & -1 \\
\hline & TSEB-PM & $\mathrm{TSC}_{\text {TEMP }}$ & 6.9 & 1.0 & 7.1 & 0.9 & 0.59 & 0.8 & 12 & 0.6 & 9 & 0.3 & 4 \\
\hline \multirow[t]{4}{*}{$15: 45$} & TSEB-PT & $\mathrm{TSC}_{\mathrm{ET}}$ & 6.9 & 1.0 & 3.5 & 1.0 & 0.20 & 3.7 & 54 & 3.4 & 49 & -3.4 & -49 \\
\hline & TSEB-PT & $\mathrm{TSC}_{\text {TEMP }}$ & 6.9 & 1.0 & 3.3 & 0.7 & 0.20 & 3.8 & 55 & 3.6 & 52 & -3.6 & -52 \\
\hline & TSEB-PM & $\mathrm{TSC}_{\mathrm{ET}}$ & 6.9 & 1.0 & 7.7 & 1.0 & 0.44 & 1.3 & 19 & 1.1 & 15 & 0.8 & 11 \\
\hline & TSEB-PM & $\mathrm{TSC}_{\text {TEMP }}$ & 6.9 & 1.0 & 7.1 & 0.9 & 0.56 & 0.9 & 12 & 0.7 & 10 & 0.2 & 3 \\
\hline
\end{tabular}

Table 3. Statistical parameters of agreement for calculated vs. measured $24 \mathrm{~h}$ ET $(n=53)$. Figures 5,6 , and 7 show scatter plots.

\begin{tabular}{|c|c|c|c|c|c|c|c|c|c|c|c|c|c|}
\hline \multirow[b]{3}{*}{ Time } & \multirow{3}{*}{$\begin{array}{l}\text { Model } \\
\text { Version }\end{array}$} & \multirow{3}{*}{$\begin{array}{c}\text { Time } \\
\text { Scaling } \\
\text { Method }\end{array}$} & \multicolumn{2}{|c|}{ Measured ET } & \multicolumn{2}{|c|}{ Calculated ET } & \multirow[b]{3}{*}{ IOA } & \multirow{2}{*}{\multicolumn{2}{|c|}{ RMSE }} & \multirow{2}{*}{\multicolumn{2}{|c|}{ MAE }} & \multirow{2}{*}{\multicolumn{2}{|c|}{ MBE }} \\
\hline & & & \multirow{2}{*}{$\begin{array}{l}\text { Avg. } \\
(\mathrm{mm})\end{array}$} & \multirow{2}{*}{$\begin{array}{c}\mathrm{SD} \\
(\mathrm{mm})\end{array}$} & \multirow{2}{*}{$\begin{array}{l}\text { Avg. } \\
(\mathrm{mm})\end{array}$} & \multirow{2}{*}{$\begin{array}{c}\mathrm{SD} \\
(\mathrm{mm})\end{array}$} & & & & & & & \\
\hline & & & & & & & & $(\mathrm{mm})$ & $(\%)$ & $(\mathrm{mm})$ & $(\%)$ & $(\mathrm{mm})$ & $(\%)$ \\
\hline \multirow[t]{2}{*}{ Summed } & TSEB-PT & None & 7.2 & 2.3 & 6.7 & 2.2 & 0.80 & 0.9 & 13 & 0.7 & 10 & -0.5 & -7 \\
\hline & TSEB-PM & None & 7.2 & 2.3 & 7.7 & 2.4 & 0.83 & 0.9 & 12 & 0.6 & 9 & 0.5 & 7 \\
\hline \multirow[t]{4}{*}{$9: 45$} & TSEB-PT & $\mathrm{TSC}_{\mathrm{ET}}$ & 7.2 & 2.3 & 5.8 & 2.1 & 0.62 & 1.8 & 25 & 1.5 & 21 & -1.4 & -20 \\
\hline & TSEB-PT & $\mathrm{TSC}_{\text {TEMP }}$ & 7.2 & 2.3 & 6.3 & 2.7 & 0.68 & 1.7 & 23 & 1.3 & 19 & -0.9 & -13 \\
\hline & TSEB-PM & $\mathrm{TSC}_{\mathrm{ET}}$ & 7.2 & 2.3 & 7.6 & 3.2 & 0.71 & 1.7 & 24 & 1.2 & 17 & 0.4 & 6 \\
\hline & TSEB-PM & $\mathrm{TSC}_{\mathrm{TEMP}}$ & 7.2 & 2.3 & 8.1 & 2.9 & 0.71 & 1.5 & 21 & 1.2 & 17 & 0.9 & 13 \\
\hline \multirow[t]{4}{*}{$11: 15$} & TSEB-PT & $\mathrm{TSC}_{\mathrm{ET}}$ & 7.2 & 2.3 & 5.5 & 1.8 & 0.55 & 1.9 & 27 & 1.7 & 24 & -1.7 & -24 \\
\hline & TSEB-PT & $\mathrm{TSC}_{\text {TEMP }}$ & 7.2 & 2.3 & 5.7 & 3.1 & 0.61 & 2.3 & 32 & 1.7 & 24 & -1.5 & -21 \\
\hline & TSEB-PM & $\mathrm{TSC}_{\mathrm{ET}}$ & 7.2 & 2.3 & 7.8 & 2.9 & 0.79 & 1.1 & 15 & 0.8 & 12 & 0.6 & 8 \\
\hline & TSEB-PM & $\mathrm{TSC}_{\text {TEMP }}$ & 7.2 & 2.3 & 7.9 & 3.0 & 0.75 & 1.3 & 18 & 1.0 & 14 & 0.7 & 10 \\
\hline \multirow[t]{4}{*}{$12: 45$} & TSEB-PT & $\mathrm{TSC}_{\mathrm{ET}}$ & 7.2 & 2.3 & 5.4 & 1.8 & 0.54 & 2.0 & 28 & 1.8 & 25 & -1.8 & -25 \\
\hline & TSEB-PT & $\mathrm{TSC}_{\text {TEMP }}$ & 7.2 & 2.3 & 5.3 & 3.8 & 0.55 & 3.2 & 44 & 2.1 & 29 & -1.9 & -26 \\
\hline & TSEB-PM & $\mathrm{TSC}_{\mathrm{ET}}$ & 7.2 & 2.3 & 7.6 & 2.7 & 0.83 & 0.9 & 13 & 0.7 & 10 & 0.4 & 5 \\
\hline & TSEB-PM & $\mathrm{TSC}_{\text {TEMP }}$ & 7.2 & 2.3 & 7.4 & 3.2 & 0.75 & 1.5 & 21 & 1.1 & 15 & 0.2 & 3 \\
\hline \multirow[t]{4}{*}{$14: 15$} & TSEB-PT & $\mathrm{TSC}_{\mathrm{ET}}$ & 7.2 & 2.3 & 5.8 & 2.1 & 0.62 & 1.8 & 24 & 1.5 & 21 & -1.4 & -20 \\
\hline & TSEB-PT & $\mathrm{TSC}_{\text {TEMP }}$ & 7.2 & 2.3 & 5.6 & 3.5 & 0.60 & 2.7 & 37 & 1.8 & 25 & -1.6 & -22 \\
\hline & TSEB-PM & $\mathrm{TSC}_{\mathrm{ET}}$ & 7.2 & 2.3 & 7.6 & 2.8 & 0.80 & 1.0 & 14 & 0.8 & 11 & 0.4 & 5 \\
\hline & TSEB-PM & $\mathrm{TSC}_{\text {TEMP }}$ & 7.2 & 2.3 & 7.3 & 3.2 & 0.76 & 1.4 & 20 & 1.0 & 14 & 0.1 & 1 \\
\hline \multirow[t]{4}{*}{$15: 45$} & TSEB-PT & $\mathrm{TSC}_{\mathrm{ET}}$ & 7.2 & 2.3 & 6.5 & 2.3 & 0.77 & 1.1 & 15 & 0.8 & 12 & -0.7 & -10 \\
\hline & TSEB-PT & $\mathrm{TSC}_{\text {TEMP }}$ & 7.2 & 2.3 & 6.2 & 2.7 & 0.73 & 1.5 & 21 & 1.1 & 15 & -1.0 & -13 \\
\hline & TSEB-PM & $\mathrm{TSC}_{\mathrm{ET}}$ & 7.2 & 2.3 & 7.6 & 2.7 & 0.80 & 1.0 & 14 & 0.8 & 11 & 0.4 & 5 \\
\hline & TSEB-PM & $\mathrm{TSC}_{\text {TEMP }}$ & 7.2 & 2.3 & 7.3 & 3.1 & 0.79 & 1.2 & 17 & 0.9 & 12 & 0.1 & 1 \\
\hline
\end{tabular}

summed values (i.e., where $15 \min T_{R}$ measurements were used and time scaling was not necessary). This was particularly the case for $\mathrm{T}$ (table 2) using the TSEB-PM. On the other hand, agreement between calculated vs. measured ET was better for summed values compared with time scaling, although the differences in model performance were nonetheless small (table 3 ).

The impact of the time of day for the one-time-of-day $T_{R}$ measurement did not show any strong trends for $\mathrm{E}$ (table 1), T (table 2), or ET (table 3 ) over the $6 \mathrm{~h} \mathrm{(} \pm 3 \mathrm{~h}$ of solar noon) time window considered. The similar model performance for summed, $\mathrm{TSC}_{\mathrm{ET}}$, and $\mathrm{TSC}_{\mathrm{TEMP}}$ methods, as well as the lack of sensitivity to the time of day for the onetime-of-day $T_{R}$ measurement, was not unexpected for a fully irrigated crop. Both the $\mathrm{TSC}_{\mathrm{ET}}$ and the form of the $\mathrm{TSC}_{\mathrm{TEMP}}$ methods as proposed in this study (i.e., $T_{R E F}$ was calculated rather than measured) are driven by micrometeorological variables. Hence, they both contain the underlying assumption that latent heat flux is coupled only to atmospheric demand, which may not apply if soil water becomes limited or if other biotic or abiotic stresses are present. If soil water is limited, for example, LE would be expected to be below atmospheric demand during the afternoon, but not necessarily in the morning (Idso et al., 1982; Jackson et al., 1981; Jackson, 1982). This would presumably result in morning $T_{R}$ values being similar to the morning non-water-stressed baseline canopy temperature, but afternoon $T_{R}$ values being elevated above the afternoon 
• Soil water evaporation (E) $\quad \triangle$ Plant transpiration $(\mathrm{T})$

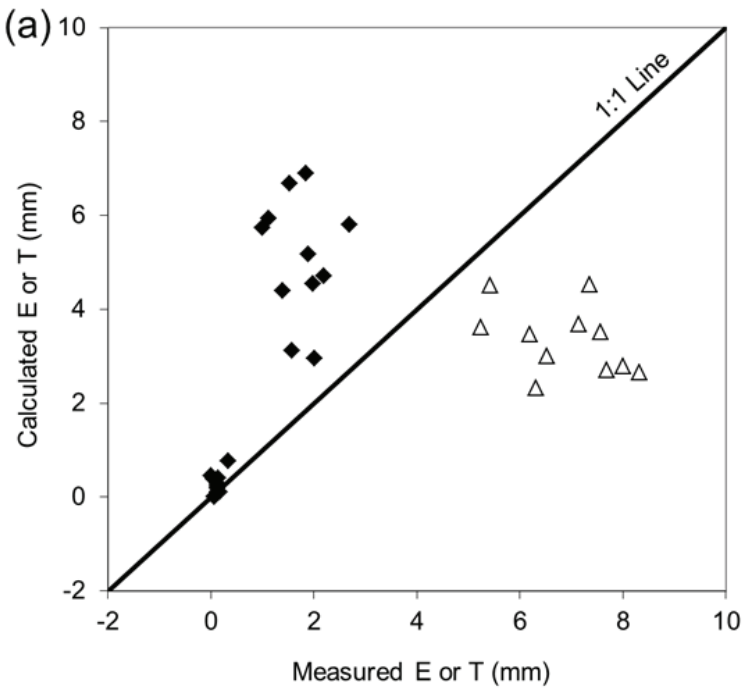

(c)

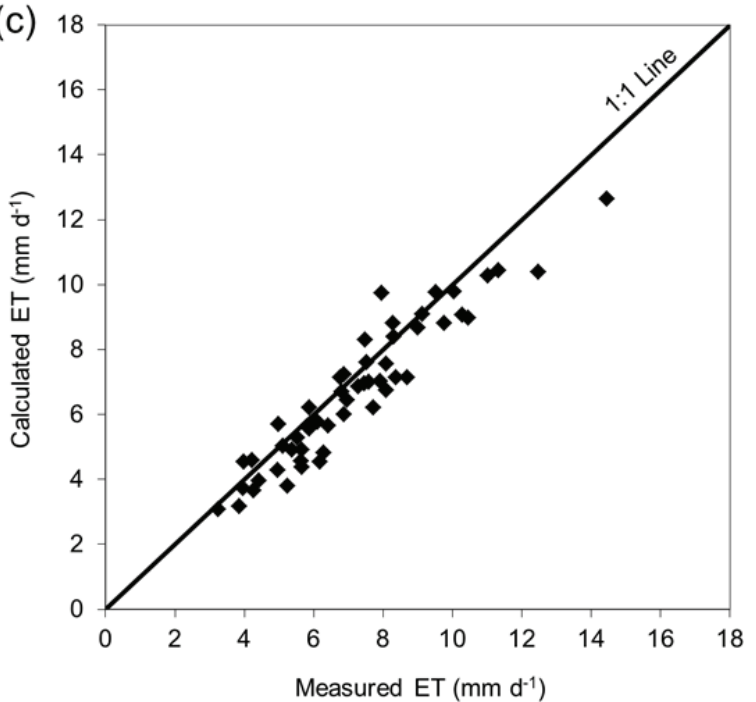

- Soil water evaporation (E) $\quad \Delta$ Plant transpiration $(\mathrm{T})$
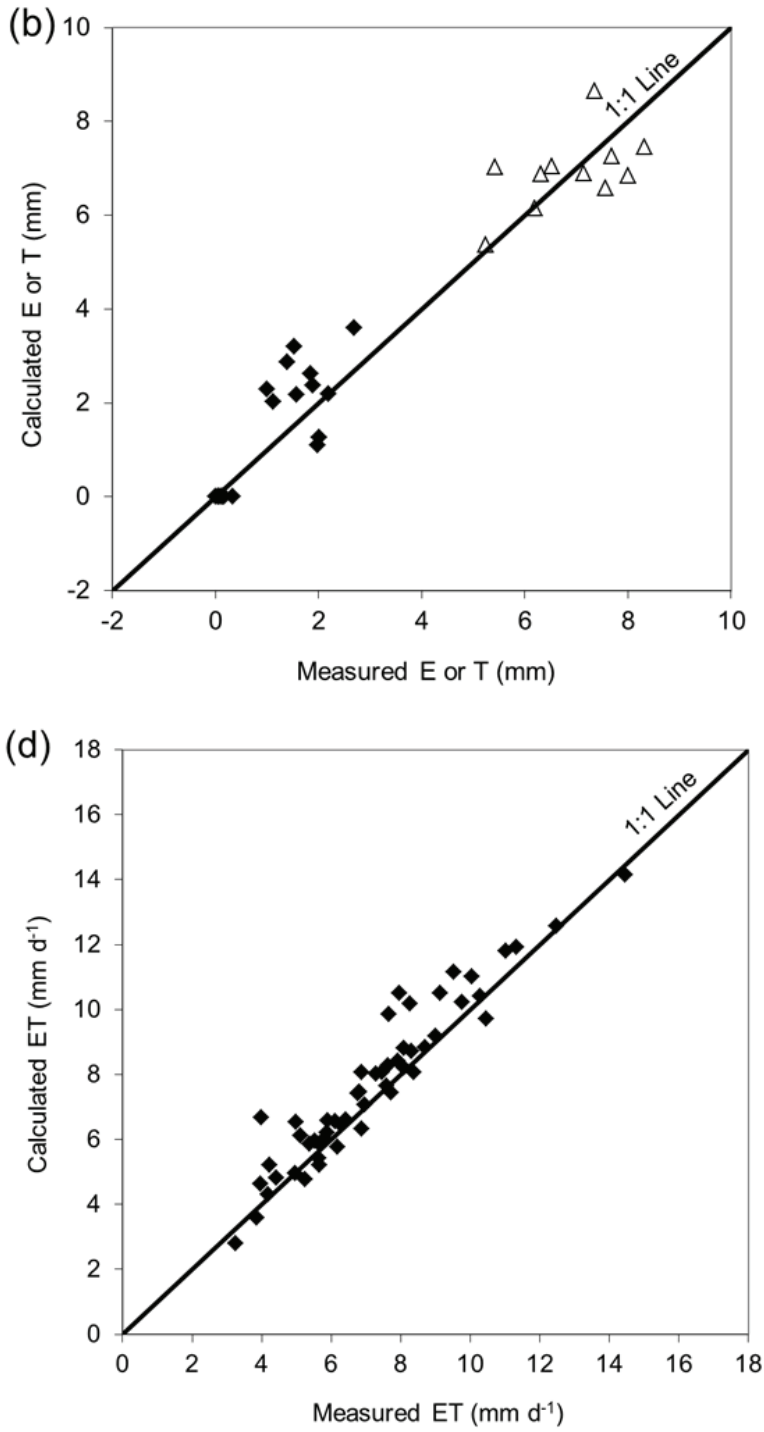

Figure 5. Calculated vs. measured $E(n=22)$ and T $(n=11)$ for (a) TSEB-PT and (b) TSEB-PM, and calculated vs. measured ET ( $n=53)$ for $(c)$ TSEB-PT and (d) TSEB-PM. Calculated E, T, and ET were the sums of 15 min intervals. Tables 1 , 2, and 3 give statistical parameters of agreement.

baseline canopy temperature. Therefore, a morning $T_{R}$ measurement could possibly result in daily latent heat flux being overestimated, and an afternoon $T_{R}$ measurement could result in daily latent heat flux being underestimated. This implies that actual measurements of $T_{R E F}$ would be advantageous over calculated values, provided that measurements could be obtained at a site or sites having limited soil water or other constraint to LE. The present study demonstrates that both the $\mathrm{TSC}_{\mathrm{ET}}$ and $\mathrm{TSC}_{\mathrm{TEMP}}$ scaling methods were suitable for use in the TSEB model for fully irrigated cotton because both methods resulted in similar calculated E, T, and ET as when these variables were summed. However, future studies should compare these and other scaling methods in water-limited conditions or other situations that would constrain LE to below atmospheric demand.

\section{DAYTIME AND NightTime ET}

Most previous TSEB studies, which used the TSEB-PT, considered either daytime-only or $24 \mathrm{~h} \mathrm{LE}$ or ET (e.g., Anderson et al., 2012; Kustas et al., 2012). Since the PriestleyTaylor equation applies only to daytime conditions, the original TSEB-PT was not intended for nighttime applications. Nonetheless, nighttime ET has been shown to be significant in a semiarid, advective climate (e.g., Tolk et al., 2006b). Therefore, we also considered TSEB model performance in terms of separate daytime (table 4 and fig. 8) and nighttime (table 5 and fig. 8) ET. As might be expected, the relative agreement between measured and calculated daytime ET followed very similar patterns as $24 \mathrm{~h}$ ET, and overall discrepancies between calculated and measured values were smaller for daytime ET compared with 24 h ET. Summed daytime ET (i.e., where time scaling was not used) resulted in somewhat better model 
- Soil water evaporation (E) $\quad \Delta$ Plant transpiration $(\mathrm{T})$
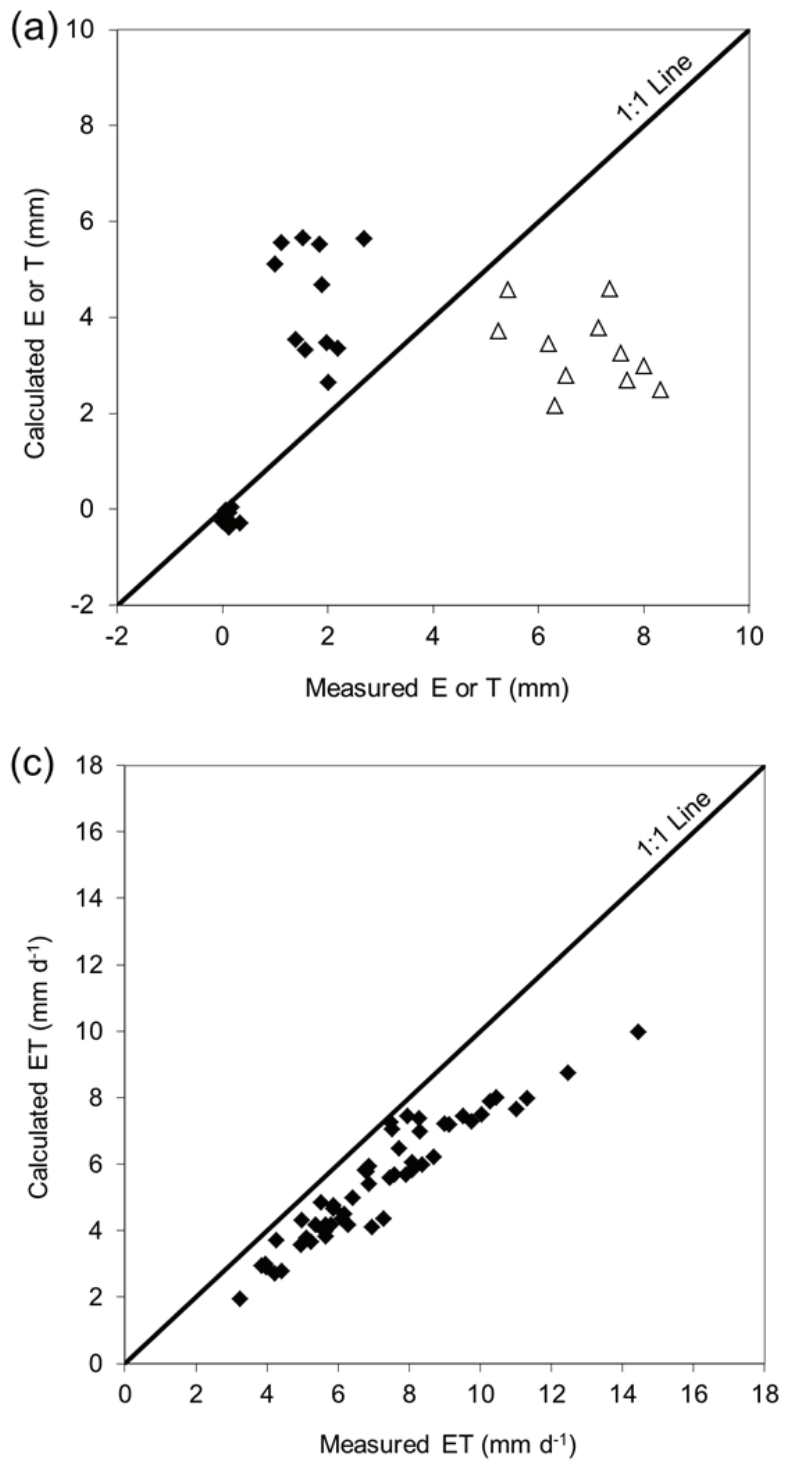

$\bullet$ Soil water evaporation (E) $\quad \triangle$ Plant transpiration $(T)$
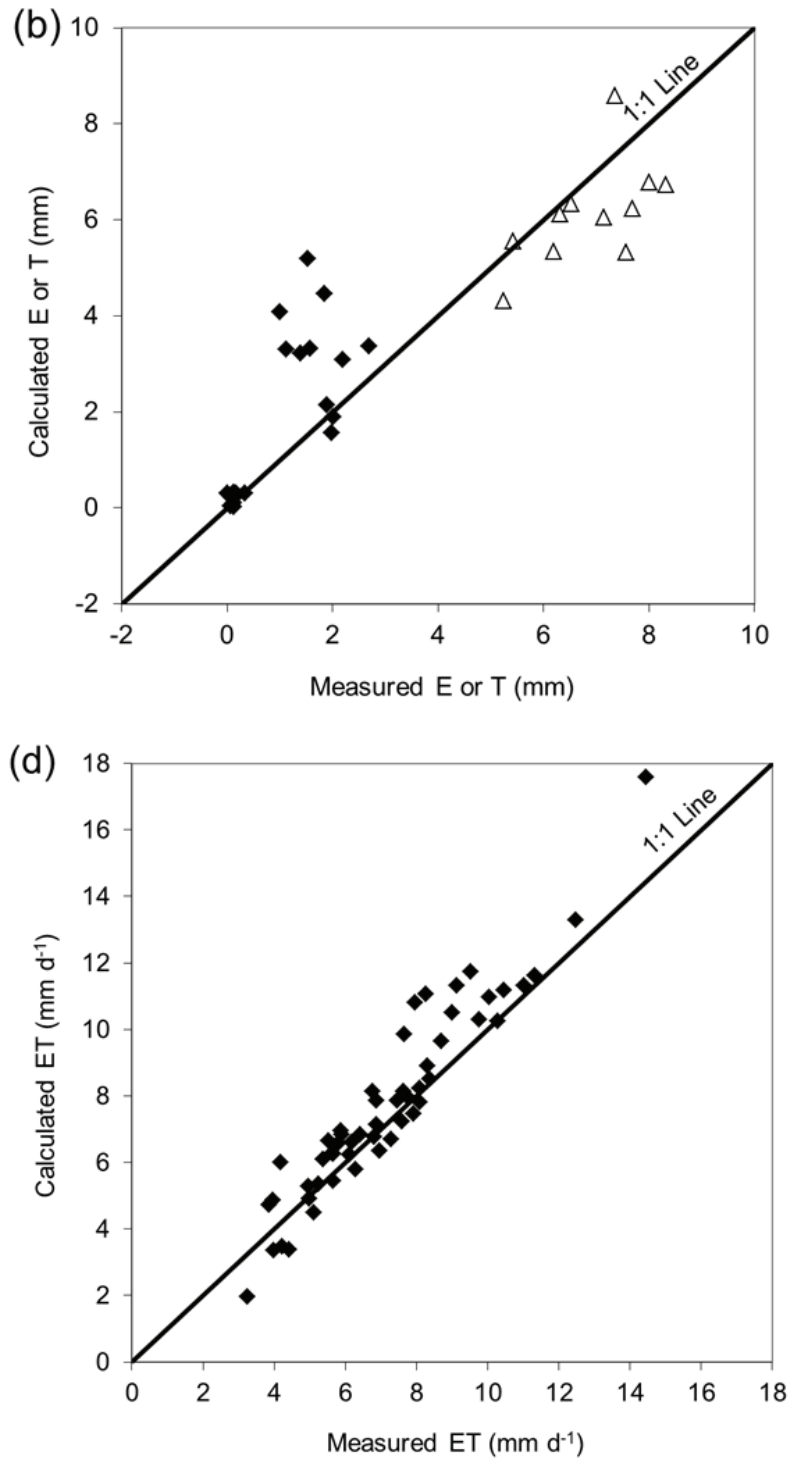

Figure 6. Calculated vs. measured E $(n=22)$ and T $(n=11)$ for $(a)$ TSEB-PT and (b) TSEB-PM, and calculated vs. measured ET ( $n=53)$ for (c) TSEB-PT and (d) TSEB-PM. E, T, and ET were calculated using one-time-of-day surface temperature measurement at 11:15 CST and scaled to the measurement duration using the TSC $_{E T}$ scaling method. Tables 1, 2, and 3 give statistical parameters of agreement.

agreement compared with $\mathrm{TSC}_{\mathrm{ET}}$ and $\mathrm{TSC}_{\mathrm{TEMP}}$, but differences in TSEB-PT vs. TSEB-PM versions were not as large compared with $24 \mathrm{~h}$ ET, and in some cases the TSEB-PT performed slightly better (e.g., $T_{R}$ measured at 9:45). MBE for the TSEB-PT ranged from -0.07 to $-0.85 \mathrm{~mm}$; TSEBPM MBE ranged from 0.003 to $0.87 \mathrm{~mm}$. In a concurrent study during BEAREX'08, Anderson et al. (2012) reported results very similar to table 4 and figure 8 for the TSEBPT, summed (i.e., no time scaling) and $\mathrm{TSC}_{\mathrm{ET}}$ at 11:15. In their study, $T_{R}$ was derived from ground-based, upwelling longwave radiation measurements and the Landsat and MODIS satellites. Daytime ET was calculated from summed values using ground-based inputs and essentially the $\mathrm{TSC}_{\mathrm{ET}}$ method using satellite inputs and compared to ET derived from lysimeter and eddy covariance measurements (see their tables 2 and 6 for comparison to the NE lysimeter). In particular, they also showed that daytime ET was underestimated compared with the largest measured values by about 1.0 to $1.6 \mathrm{~mm} \mathrm{~d}^{-1}$ (where their $\mathrm{MJ} \mathrm{m} \mathrm{m}^{-2} \mathrm{~d}^{-1}$ units were converted to $\mathrm{mm}$ ).

In sharp contrast to daytime ET, calculated nighttime ET values were highly dependent on which TSEB version was used (table 5 and fig. 8). The relative discrepancies between calculations and measurements were greater for nighttime ET than daytime or $24 \mathrm{~h}$ ET for all TSEB versions. This would be expected because all energy fluxes at night were much smaller compared with daytime fluxes; therefore, lysimeter measurements and model inputs would be prone to greater relative error. The average of measured nighttime ET was $0.47 \mathrm{~mm}(6.6 \%$ of $24 \mathrm{~h} \mathrm{ET})$, and nighttime ET ranged from -0.054 to $1.4 \mathrm{~mm}$. Only one measured nighttime ET value was negative $(-0.054 \mathrm{~mm})$ and occurred on DOY 233, which resulted from a small 
- Soil water evaporation $(\mathrm{E}) \quad \triangle$ Plant transpiration $(\mathrm{T})$
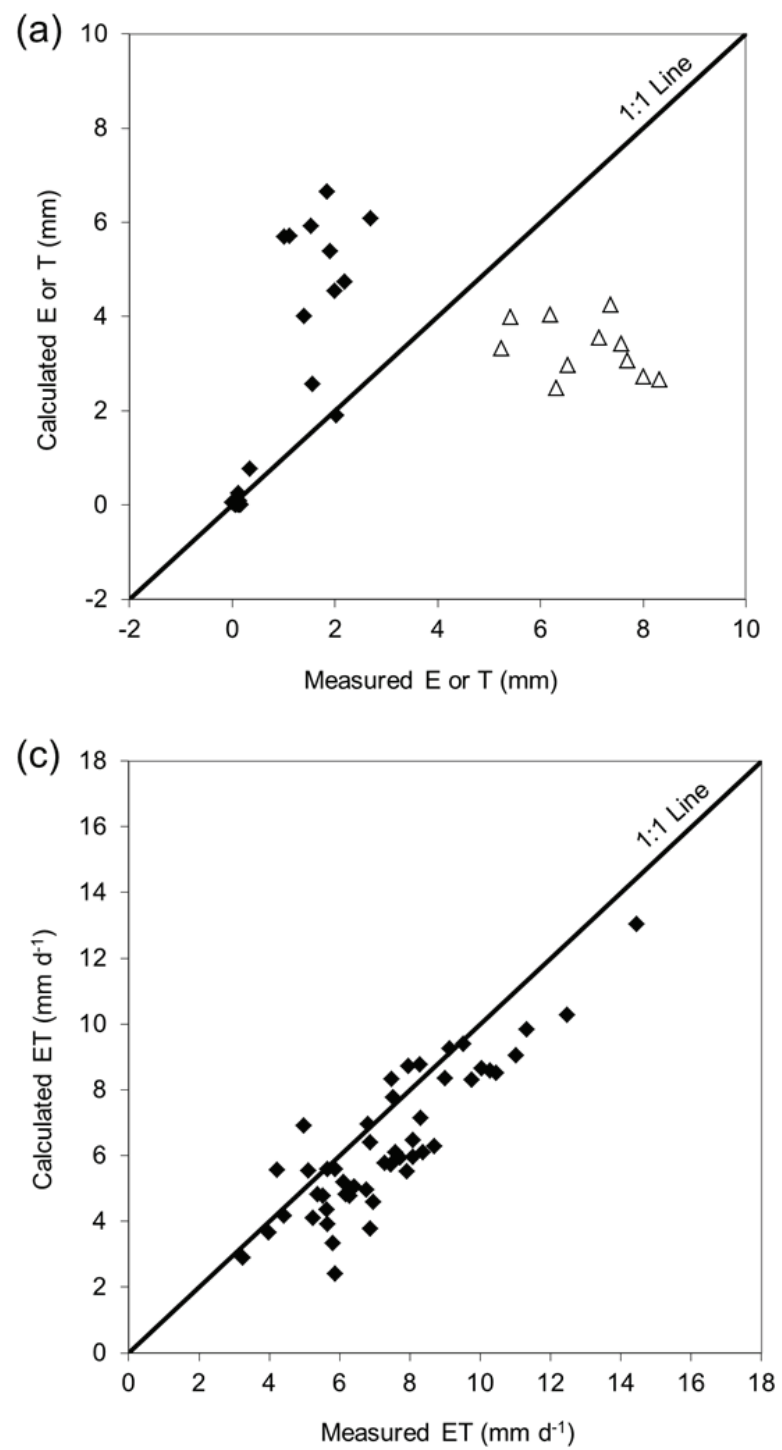

rain gauge. The smallest positive ET value was $0.0055 \mathrm{~mm}$. Tolk et al. (2006b) reported similar nighttime ET ranges for irrigated cotton at our study location, but average nighttime ET for irrigated alfalfa (Medicago sativa L.) was greater $(0.55 \mathrm{~mm})$ and was sometimes nearly $2 \mathrm{~mm}$. Therefore, nighttime ET can be a significant component of $24 \mathrm{~h}$ ET. The TSEB-PT consistently underestimated nighttime ET; about half of the calculated values were negative where ET was summed, and most values were negative for the $\mathrm{TSC}_{\mathrm{ET}}$ and $\mathrm{TSC}_{\text {TEMP }}$ methods. The TSEB-PM, however, resulted in only one negative value for summed ET (DOY 181) versus six negative values for $\mathrm{TSC}_{\mathrm{TEMP}}$, which were all early in the season during partial canopy cover (DOY 178 to 188). The TSEB-PM TSC $\mathrm{TST}_{\mathrm{ET}}$ version resulted in the best agreement between measured and calculated nighttime ET; somewhat surprisingly, this was even better compared with summed values. This implies that nighttime ET for fully
- Soil water evaporation (E) $\quad \triangle$ Plant transpiration $(\mathrm{T})$
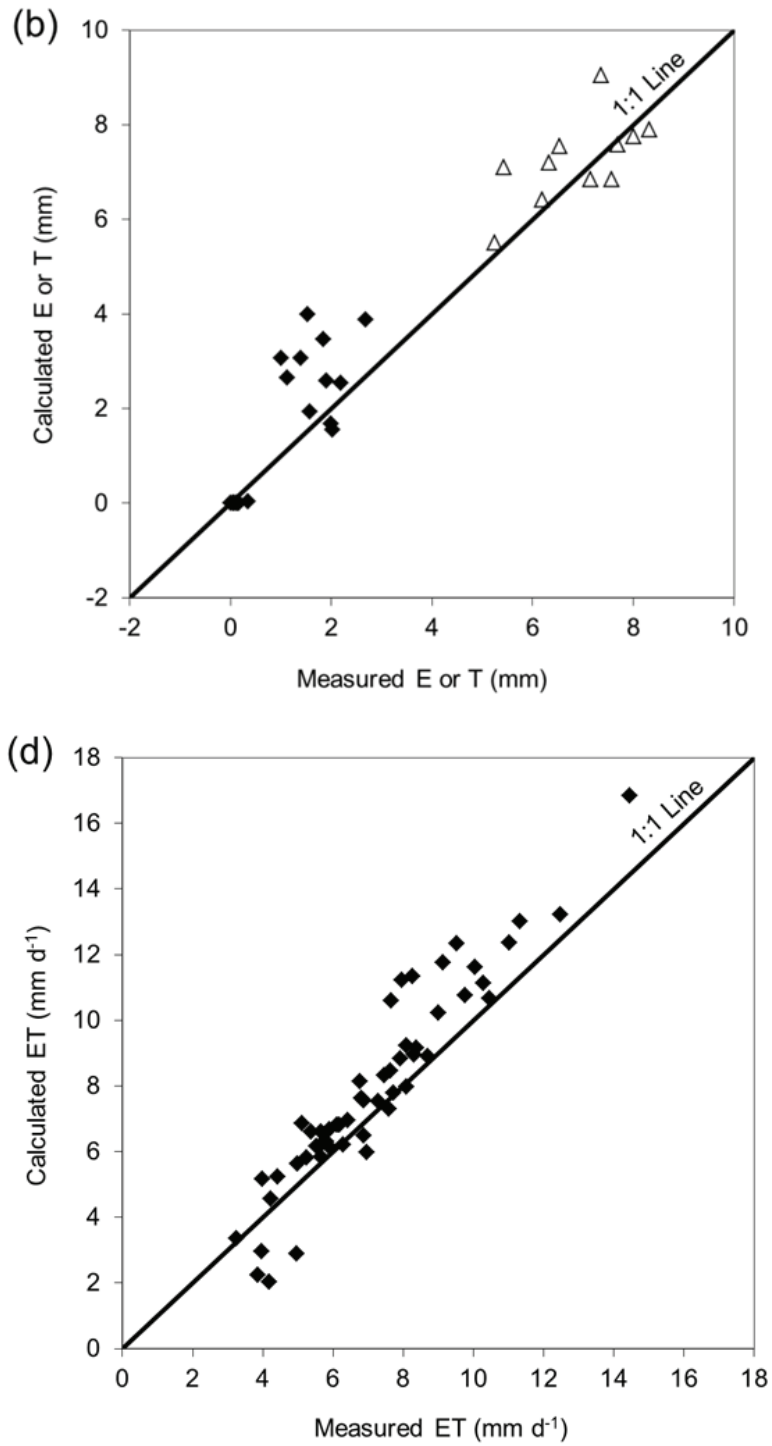

irrigated cotton was more strongly correlated to nighttime reference ET calculated with the Penman-Monteith equation than latent heat flux calculated with the TSEB-PM. The average calculated nighttime and $24 \mathrm{~h}$ reference ET were 0.38 and $6.4 \mathrm{~mm}$, respectively, where nighttime was $5.9 \%$ of $24 \mathrm{~h}$ average values. These values were similar to the respective ET values measured with the lysimeter. However, in the TSEB, small errors in the surface-air temperature gradient and calculated resistances at night probably led to relatively large errors in turbulent heat flux calculations, since the available energy was relatively small. The frequent calculation of negative nighttime ET values using the TSEB-PT was related to initial $\mathrm{LE}_{C}\left(\mathrm{LE}_{C I}\right.$, eq. 1) always being positive (i.e., toward the canopy) because nighttime $R_{N, C}$ is negative (i.e., away from the canopy). This contrasts with the Penman-Monteith $\mathrm{LE}_{C I}$ (eq. 2), which may be either positive or negative, depending on the relative magni- 
Table 4. Statistical parameters of agreement for calculated vs. measured daytime ET ( $n=53)$. Figure 8 shows scatter plots.

\begin{tabular}{|c|c|c|c|c|c|c|c|c|c|c|c|c|c|}
\hline \multirow[b]{3}{*}{ Time } & \multirow{3}{*}{$\begin{array}{c}\text { Model } \\
\text { Version }\end{array}$} & \multirow{3}{*}{$\begin{array}{c}\text { Time } \\
\text { Scaling } \\
\text { Method }\end{array}$} & \multicolumn{2}{|c|}{$\begin{array}{c}\text { Measured } \\
\text { Day ET }\end{array}$} & \multicolumn{2}{|c|}{$\begin{array}{c}\text { Calculated } \\
\text { Day ET }\end{array}$} & \multirow[b]{3}{*}{ IOA } & \multirow{2}{*}{\multicolumn{2}{|c|}{ RMSE }} & \multirow{2}{*}{\multicolumn{2}{|c|}{ MAE }} & \multirow{2}{*}{\multicolumn{2}{|c|}{ MBE }} \\
\hline & & & \multirow{2}{*}{$\begin{array}{l}\text { Avg. } \\
(\mathrm{mm})\end{array}$} & \multirow{2}{*}{$\begin{array}{c}\mathrm{SD} \\
(\mathrm{mm})\end{array}$} & \multirow{2}{*}{$\begin{array}{l}\text { Avg. } \\
(\mathrm{mm})\end{array}$} & \multirow{2}{*}{$\begin{array}{c}\mathrm{SD} \\
(\mathrm{mm})\end{array}$} & & & & & & & \\
\hline & & & & & & & & $(\mathrm{mm})$ & $(\%)$ & $(\mathrm{mm})$ & $(\%)$ & $(\mathrm{mm})$ & $(\%)$ \\
\hline Summed & TSEB-PT & None & 6.7 & 2.1 & 6.6 & 2.2 & 0.87 & 0.6 & 8 & 0.5 & 7 & -0.1 & -1 \\
\hline & TSEB-PM & None & 6.7 & 2.1 & 6.9 & 2.4 & 0.89 & 0.6 & 8 & 0.4 & 6 & 0.2 & 3 \\
\hline $9: 45$ & TSEB-PT & $\mathrm{TSC}_{\mathrm{ET}}$ & 6.7 & 2.1 & 6.2 & 2.2 & 0.76 & 1.1 & 16 & 0.8 & 13 & -0.5 & -7 \\
\hline & TSEB-PT & $\mathrm{TSC}_{\text {TEMP }}$ & 6.7 & 2.1 & 6.5 & 2.5 & 0.78 & 1.1 & 16 & 0.8 & 12 & -0.2 & -3 \\
\hline & TSEB-PM & $\mathrm{TSC}_{\mathrm{ET}}$ & 6.7 & 2.1 & 7.2 & 3.0 & 0.70 & 1.6 & 24 & 1.2 & 18 & 0.5 & 7 \\
\hline & TSEB-PM & $\mathrm{TSC}_{\mathrm{TEMP}}$ & 6.7 & 2.1 & 7.6 & 2.7 & 0.70 & 1.4 & 21 & 1.1 & 17 & 0.9 & 13 \\
\hline $11: 15$ & TSEB-PT & $\mathrm{TSC}_{\mathrm{ET}}$ & 6.7 & 2.1 & 5.9 & 1.9 & 0.75 & 1.0 & 15 & 0.9 & 13 & -0.8 & -12 \\
\hline & TSEB-PT & $\mathrm{TSC}_{\mathrm{TEMP}}$ & 6.7 & 2.1 & 6.0 & 2.7 & 0.75 & 1.4 & 20 & 1.0 & 15 & -0.7 & -11 \\
\hline & TSEB-PM & $\mathrm{TSC}_{\mathrm{ET}}$ & 6.7 & 2.1 & 7.3 & 2.6 & 0.78 & 1.1 & 16 & 0.8 & 12 & 0.6 & 8 \\
\hline & TSEB-PM & $\mathrm{TSC}_{\text {TEMP }}$ & 6.7 & 2.1 & 7.4 & 2.7 & 0.80 & 1.1 & 16 & 0.8 & 12 & 0.7 & 10 \\
\hline $12: 45$ & TSEB-PT & $\mathrm{TSC}_{\mathrm{ET}}$ & 6.7 & 2.1 & 5.9 & 1.9 & 0.73 & 1.1 & 16 & 0.9 & 14 & -0.8 & -13 \\
\hline & TSEB-PT & $\mathrm{TSC}_{\text {TEMP }}$ & 6.7 & 2.1 & 5.6 & 3.2 & 0.68 & 2.1 & 31 & 1.3 & 19 & -1.1 & -16 \\
\hline & TSEB-PM & $\mathrm{TSC}_{\mathrm{ET}}$ & 6.7 & 2.1 & 7.1 & 2.5 & 0.83 & 0.9 & 13 & 0.6 & 10 & 0.4 & 6 \\
\hline & TSEB-PM & $\mathrm{TSC}_{\text {TEMP }}$ & 6.7 & 2.1 & 6.9 & 2.8 & 0.82 & 1.0 & 15 & 0.7 & 11 & 0.2 & 3 \\
\hline $14: 15$ & TSEB-PT & $\mathrm{TSC}_{\mathrm{ET}}$ & 6.7 & 2.1 & 6.2 & 2.2 & 0.77 & 1.0 & 15 & 0.8 & 12 & -0.5 & -7 \\
\hline & TSEB-PT & $\mathrm{TSC}_{\text {TEMP }}$ & 6.7 & 2.1 & 5.9 & 3.0 & 0.73 & 1.7 & 26 & 1.1 & 16 & -0.8 & -12 \\
\hline & TSEB-PM & $\mathrm{TSC}_{\mathrm{ET}}$ & 6.7 & 2.1 & 7.1 & 2.6 & 0.80 & 0.9 & 14 & 0.8 & 11 & 0.4 & 6 \\
\hline & TSEB-PM & $\mathrm{TSC}_{\mathrm{TEMP}}$ & 6.7 & 2.1 & 6.7 & 2.9 & 0.81 & 1.0 & 15 & 0.7 & 11 & 0.0 & 0 \\
\hline $15: 45$ & TSEB-PT & $\mathrm{TSC}_{\mathrm{ET}}$ & 6.7 & 2.1 & 7.0 & 2.4 & 0.82 & 0.8 & 12 & 0.7 & 10 & 0.3 & 5 \\
\hline & TSEB-PT & $\mathrm{TSC}_{\text {TEMP }}$ & 6.7 & 2.1 & 6.6 & 2.4 & 0.84 & 0.8 & 12 & 0.6 & 9 & -0.1 & -2 \\
\hline & TSEB-PM & $\mathrm{TSC}_{\mathrm{ET}}$ & 6.7 & 2.1 & 7.1 & 2.5 & 0.80 & 0.9 & 14 & 0.8 & 11 & 0.4 & 6 \\
\hline & TSEB-PM & $\mathrm{TSC}_{\text {TEMP }}$ & 6.7 & 2.1 & 6.7 & 2.7 & 0.84 & 0.8 & 12 & 0.6 & 9 & 0.0 & 0 \\
\hline
\end{tabular}

Table 5. Statistical parameters of agreement for calculated vs. measured nighttime ET $(\boldsymbol{n}=\mathbf{5 3})$. Figure 8 shows scatter plots.

\begin{tabular}{|c|c|c|c|c|c|c|c|c|c|c|c|c|c|}
\hline \multirow[b]{3}{*}{ Time } & \multirow{3}{*}{$\begin{array}{l}\text { Model } \\
\text { Version }\end{array}$} & \multirow{3}{*}{$\begin{array}{l}\text { Time } \\
\text { Scaling } \\
\text { Method }\end{array}$} & \multicolumn{2}{|c|}{$\begin{array}{l}\text { Measured } \\
\text { Night ET }\end{array}$} & \multicolumn{2}{|c|}{$\begin{array}{l}\text { Calculated } \\
\text { Night ET }\end{array}$} & \multirow[b]{3}{*}{ IOA } & \multirow{2}{*}{\multicolumn{2}{|c|}{ RMSE }} & \multirow{2}{*}{\multicolumn{2}{|c|}{ MAE }} & \multirow{2}{*}{\multicolumn{2}{|c|}{ MBE }} \\
\hline & & & \multirow{2}{*}{$\begin{array}{l}\text { Avg. } \\
(\mathrm{mm})\end{array}$} & \multirow{2}{*}{$\begin{array}{c}\mathrm{SD} \\
(\mathrm{mm})\end{array}$} & \multirow{2}{*}{$\begin{array}{l}\text { Avg. } \\
(\mathrm{mm})\end{array}$} & \multirow{2}{*}{$\begin{array}{c}\mathrm{SD} \\
(\mathrm{mm})\end{array}$} & & & & & & & \\
\hline & & & & & & & & $(\mathrm{mm})$ & $(\%)$ & $(\mathrm{mm})$ & $(\%)$ & $(\mathrm{mm})$ & $(\%)$ \\
\hline \multirow[t]{2}{*}{ Summed } & TSEB-PT & None & 0.47 & 0.24 & 0.0 & 0.3 & 0.21 & 0.6 & 122 & 0.5 & 103 & -0.4 & -91 \\
\hline & TSEB-PM & None & 0.47 & 0.24 & 0.8 & 0.4 & 0.26 & 0.6 & 131 & 0.4 & 83 & 0.3 & 60 \\
\hline \multirow[t]{4}{*}{$9: 45$} & TSEB-PT & $\mathrm{TSC}_{\mathrm{ET}}$ & 0.47 & 0.24 & -0.5 & 0.2 & 0.15 & 1.0 & 219 & 1.0 & 201 & -1.0 & -201 \\
\hline & TSEB-PT & $\mathrm{TSC}_{\mathrm{TEMP}}$ & 0.47 & 0.24 & -0.3 & 0.7 & 0.11 & 1.1 & 222 & 0.9 & 197 & -0.7 & -155 \\
\hline & TSEB-PM & $\mathrm{TSC}_{\mathrm{ET}}$ & 0.47 & 0.24 & 0.4 & 0.3 & 0.68 & 0.2 & 34 & 0.1 & 26 & 0.0 & -6 \\
\hline & TSEB-PM & $\mathrm{TSC}_{\mathrm{TEMP}}$ & 0.47 & 0.24 & 0.5 & 0.5 & 0.34 & 0.5 & 109 & 0.4 & 75 & 0.1 & 16 \\
\hline \multirow[t]{4}{*}{$11: 15$} & TSEB-PT & $\mathrm{TSC}_{\mathrm{ET}}$ & 0.47 & 0.24 & -0.5 & 0.2 & 0.15 & 1.0 & 213 & 0.9 & 196 & -0.9 & -196 \\
\hline & TSEB-PT & $\mathrm{TSC}_{\mathrm{TEMP}}$ & 0.47 & 0.24 & -0.3 & 0.8 & 0.09 & 1.1 & 240 & 1.0 & 200 & -0.7 & -157 \\
\hline & TSEB-PM & $\mathrm{TSC}_{\mathrm{ET}}$ & 0.47 & 0.24 & 0.5 & 0.3 & 0.70 & 0.1 & 29 & 0.1 & 23 & 0.0 & -4 \\
\hline & TSEB-PM & $\mathrm{TSC}_{\mathrm{TEMP}}$ & 0.47 & 0.24 & 0.5 & 0.6 & 0.29 & 0.6 & 136 & 0.4 & 93 & 0.1 & 12 \\
\hline \multirow[t]{4}{*}{$12: 45$} & TSEB-PT & $\mathrm{TSC}_{\mathrm{ET}}$ & 0.47 & 0.24 & -0.5 & 0.2 & 0.16 & 1.0 & 210 & 0.9 & 195 & -0.9 & -195 \\
\hline & TSEB-PT & $\mathrm{TSC}_{\mathrm{TEMP}}$ & 0.47 & 0.24 & -0.3 & 0.9 & 0.09 & 1.2 & 259 & 1.0 & 204 & -0.8 & -169 \\
\hline & TSEB-PM & $\mathrm{TSC}_{\mathrm{ET}}$ & 0.47 & 0.24 & 0.4 & 0.3 & 0.66 & 0.1 & 31 & 0.1 & 26 & 0.0 & -8 \\
\hline & TSEB-PM & $\mathrm{TSC}_{\mathrm{TEMP}}$ & 0.47 & 0.24 & 0.5 & 0.7 & 0.25 & 0.7 & 156 & 0.5 & 104 & 0.0 & 5 \\
\hline \multirow[t]{4}{*}{$14: 15$} & TSEB-PT & $\mathrm{TSC}_{\mathrm{ET}}$ & 0.47 & 0.24 & -0.5 & 0.2 & 0.15 & 1.0 & 217 & 1.0 & 200 & -1.0 & -200 \\
\hline & TSEB-PT & $\mathrm{TSC}_{\mathrm{TEMP}}$ & 0.47 & 0.24 & -0.3 & 0.7 & 0.12 & 1.1 & 233 & 0.9 & 182 & -0.8 & -168 \\
\hline & TSEB-PM & $\mathrm{TSC}_{\mathrm{ET}}$ & 0.47 & 0.24 & 0.4 & 0.3 & 0.65 & 0.2 & 32 & 0.1 & 28 & 0.0 & -8 \\
\hline & TSEB-PM & $\mathrm{TSC}_{\mathrm{TEMP}}$ & 0.47 & 0.24 & 0.5 & 0.8 & 0.24 & 0.8 & 163 & 0.5 & 110 & 0.1 & 13 \\
\hline \multirow[t]{4}{*}{$15: 45$} & TSEB-PT & $\mathrm{TSC}_{\mathrm{ET}}$ & 0.47 & 0.24 & -0.5 & 0.2 & 0.14 & 1.1 & 231 & 1.0 & 214 & -1.0 & -214 \\
\hline & TSEB-PT & $\mathrm{TSC}_{\mathrm{TEMP}}$ & 0.47 & 0.24 & -0.3 & 0.5 & 0.16 & 1.0 & 204 & 0.8 & 173 & -0.8 & -169 \\
\hline & TSEB-PM & $\mathrm{TSC}_{\mathrm{ET}}$ & 0.47 & 0.24 & 0.4 & 0.3 & 0.65 & 0.2 & 32 & 0.1 & 28 & 0.0 & -8 \\
\hline & TSEB-PM & $\mathrm{TSC}_{\text {TEMP }}$ & 0.47 & 0.24 & 0.5 & 0.7 & 0.24 & 0.7 & 154 & 0.5 & 107 & 0.1 & 12 \\
\hline
\end{tabular}

tudes of the energy or aerodynamic terms. In the TSEB-PT, positive $\mathrm{LE}_{C I}$ often resulted in final $\mathrm{LE}_{C}$ and $\mathrm{LE}$ being positive (since $\mathrm{LE}_{S}$ is constrained from being positive) following solution of the energy balance by the secant method, and hence calculated ET was negative. In the present study, $\mathrm{LE}_{C}$ was not constrained from being positive to allow for the possibility of nighttime condensation on the canopy. Calculation of final energy flux components is based on calculating the series network of temperatures and resistances, and the final calculated $T_{C}$ in the TSEB-PT was usually overestimated during both night and day. This can occur for both $T_{C}>T_{A C}$ and $T_{C}<T_{A C}$, resulting in $H_{C}$ being either negative or positive, respectively, from equation 6 .
At night when $R_{N, C}$ is negative, negative $H_{C}$ results in positive $\mathrm{LE}_{C}$ from equation $4 \mathrm{a}$. In addition, if $H_{C}$ is positive but $\left|R_{N, \mathrm{C}}\right|>H_{C}$, then $\mathrm{LE}_{C}$ is also positive (eq. $4 \mathrm{a}$ ).

\section{CONCLUSION}

The TSEB-PT consistently overestimated $\mathrm{E}$ and underestimated T, with MBE up to $1.8 \mathrm{~mm}$ and $-3.9 \mathrm{~mm}$, respectively compared with measurements. However, the TSEB$\mathrm{PM}$ resulted in $\mathrm{E}$ and $\mathrm{T} \mathrm{MBE}$ of $0.79 \mathrm{~mm}$ and $\pm 0.76 \mathrm{~mm}$, respectively, compared with measurements. Discrepancies between calculated and measured $\mathrm{T}$ were significantly cor- 

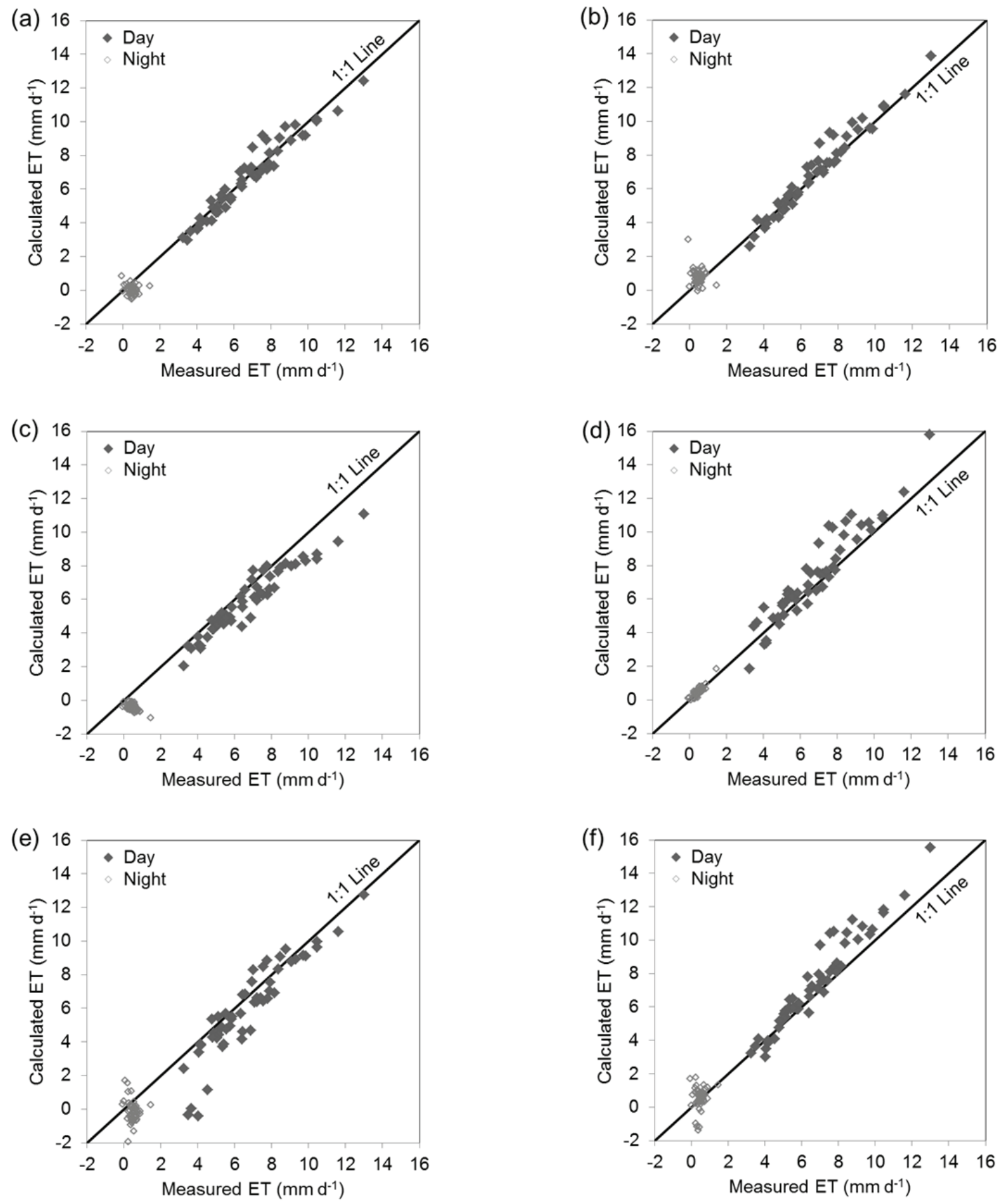

Figure 8. Calculated vs. measured day and night ET for (a) TSEB-PT summed, (b) TSEB-PM summed, (c) TSEB-PT TSC ET $_{\text {, (d) TSEB-PM }}$ TSC $_{\text {ET }}$, (e) TSEB-PT TSC TEMP, $_{\text {, and (f) TSEB-PM TSC }}$ TEMP. The TSC ET $_{\text {ET }}$ and TSC $_{\text {TEMP }}$ scaling methods used one-time-of-day surface temperature measurements at 11:15 CST. Tables 4 and 5 give statistical parameters of agreement.

related with VPD for the TSEB-PT but not for the TSEBPM, which showed that the TSEB-PM was able to capture the strong influence of VPD over $\mathrm{T}$ in these ecosystems. The TSEB-PT and TSEB-PM both resulted in similar and relatively smaller discrepancies between calculated and measured daytime and $24 \mathrm{~h} \mathrm{ET}$, although the discrepancies were somewhat less for the TSEB-PM. Nighttime ET measurements were low but always greater than zero except for one instance; however, the TSEB-PT often calcu- lated negative values when these were summed from 15 min calculations, and values were nearly always negative when time scaling was used. This was related to assumptions in the Priestley-Taylor equation applying to daytime conditions only. On the other hand, the TSEB-PM resulted in calculated negative nighttime ET in only a few instances and resulted in much better agreement with measured nighttime ET. At all times, summed calculations of E, T, and ET (i.e., where no time scaling was used) gen- 
erally had better agreement with measurements compared with time scaling. The $\mathrm{TSC}_{\mathrm{ET}}$ and $\mathrm{TSC}_{\mathrm{TEMP}}$ time scaling methods did not differ greatly for $24 \mathrm{~h}$ ET values, but the TSEB-PM TSC $_{\mathrm{ET}}$ version resulted in far better model agreement for nighttime ET (RMSE/MBE up to 0.16/-0.04 $\mathrm{mm}$ ) compared with the summed or $\mathrm{TSC}_{\mathrm{TEMP}}$ methods (RMSE/MBE up to $0.77 / 0.29 \mathrm{~mm}$ ). Both the $\mathrm{TSC}_{\mathrm{ET}}$ and $\mathrm{TSC}_{\mathrm{TEMP}}$ time scaling methods were relatively insensitive to the time of day of the $T_{R}$ measurement, although discrepancies between calculations and measurements were generally larger for the morning (i.e., 9:45 CST). Both time scaling methods have the same data requirements, but $\mathrm{TSC}_{\mathrm{ET}}$ may be advantageous over $\mathrm{TSC}_{\mathrm{TEMP}}$ when nighttime $\mathrm{ET}$ calculation is of interest. It should be noted that these results were obtained for a fully irrigated crop where latent heat flux was constrained mainly by atmospheric demand, which may have masked differences in the choice of time scaling methods or time of day of the $T_{R}$ measurement. Therefore, future TSEB studies where time scaling is used should also consider non-fully irrigated, dryland, and natural vegetation under water-limited conditions.

\section{ACKNOWLEDGEMENTS}

This research was supported by the USDA-ARS National Program 211, Water Availability and Watershed Management, and in part by the Ogallala Aquifer Program, a consortium between the USDA Agricultural Research Service, Kansas State University, Texas AgriLife Research, Texas AgriLife Extension Service, Texas Tech University, and West Texas A\&M University. We thank the numerous biological technicians and student workers for their meticulous and dedicated efforts in executing experiments and obtaining and processing data.

\section{REFERENCES}

Agam, N., Kustas, W. P., Anderson, M. C., Norman, J. M., Colaizzi, P. D., Howell, T. A., Prueger, J. H., Meyers, T. P., \& Wilson, T. B. (2010). Application of the Priestley-Taylor approach in a two-source surface energy balance model. $J$. Hydrometeorol., 11(2), 185-198.

http://dx.doi.org/10.1175/2009JHM1124.1.

Agam, N., Evett, S. R., Tolk, J. A., Kustas, W. P., Colaizzi, P. D., Alfieri, J. G., McKee, L. G., Copeland, K. S., Howell, T. A., \& Chávez, J. L. (2012). Evaporative loss from irrigated interrows in a highly advective semi-arid agricultural area. $A d v$. Water Resources, 50, 20-30.

Alfieri, J. G., Kustas, W. P., Prueger, J. H., Hipps, L. E., Evett, S. R., Basara, J. B., Neale, C. M. U., French, A. N., Colaizzi, P., Agam, N., Cosh, M. H., Chavez, J. L., \& Howell, T. A. (2012). On the discrepancy between eddy covariance and lysimetrybased surface flux measurements under strongly advective conditions. Adv. Water Resources, 50, 62-78. http://dx.doi.org/10.1016/j.advwatres.2012.07.008.

Allen, R. G., Pereira, L. S., Raes, D., \& Smith, M. (1998). Crop evapotranspiration: Guidelines for computing crop water requirements. Irrigation and Drainage Paper No. 56. Rome, Italy: United Nations FAO.

Allen, R. G., Walter, I. A., Elliott, R. L., Howell, T. A., Itenfisu, D., Jensen, M. E., \& Snyder, R. L. (2005). The ASCE standardized reference evapotranspiration equation. ASCE/EWRI Task Committee Report. Reston, Va.: ASCE.
Allen, R. G., Pruitt, W. O., Wright, J. L., Howell, T. A., Ventura, F., Snyder, R., Itenfisu, D., Steduto, P., Berengena, J., Yrisarry, J. B., Smith, M., Pereira, L. S., Raes, D., Perrier, A., Alves, I., Walter, I., \& Elliot, R. (2006). A recommendation on standardized surface resistance for hourly calculation of reference $\mathrm{ET}_{o}$ by the FAO 56 Penman-Monteith method. Agric. Water Mgmt., 81(1-2), 1-22. http://dx.doi.org/10.1016/j.agwat.2005.03.007.

Anderson, M. C., Norman, J. M., Diak, G. R., Kustas, W. P., \& Mecikalski, J. R. (1997). A two-source time-integrated model for estimating surface fluxes using thermal infrared remote sensing. Remote Sensing Environ., 60(2), 195-216. http://dx.doi.org/10.1016/S0034-4257(96)00215-5.

Anderson, M. C., Norman, J. M., Kustas, W. P., Li, F., Prueger, J. H., \& Mecikalski, J. R. (2005). Effects of vegetation clumping on two-source model estimates of surface energy fluxes from an agricultural landscape during SMACEX. J. Hydrometeorol., 6(6), 892-909. http://dx.doi.org/10.1175/JHM465.1.

Anderson, M. C., Kustas, W. P., Alfieri, J. G., Gao, F., Hain, C., Prueger, J. H., Evett, S. R., Colaizzi, P. D., Howell, T. A., \& Chavez, J. L. (2012). Mapping daily evapotranspiration at Landsat spatial scales during the BEAREX'08 field campaign. Adv. Water Resources, 50, 162-177. http://dx.doi.org/10.1016/j.advwatres.2012.06.005.

Baker, J. M., \& van Bavel, C. H. (1987). Measurement of the mass flow of water in the stems of herbaceous plants. Plant Cell Environ., 10(9), 777-782.

Cammalleri, C., Ciraolo, G., La Loggia, G., \& Maltese, A. (2012). Daily evapotranspiration assessment by means of residual surface energy balance modeling: A critical analysis under a wide range of water availability. J. Hydrol., 452-453, 119-129. http://dx.doi.org/10.1016/j.jhydrol.2012.05.042.

Campbell, G. S., \& Norman, J. M. (1998). An Introduction to Environmental Biophysics (2nd ed.). New York, N.Y.: SpringerVerlag. http://dx.doi.org/10.1007/978-1-4612-1626-1.

Colaizzi, P. D., Evett, S. R., Howell, T. A., \& Tolk, J. A. (2006) Comparison of five models to scale daily evapotranspiration from one-time-of-day measurements. Trans. ASABE, 49(5), 1409-1417. http://dx.doi.org/10.13031/2013.22056.

Colaizzi, P. D., O'Shaughnessy, S. A., Gowda, P. H., Evett, S. R., Howell, T. A., Kustas, W. P., \& Anderson, M. C. (2010). Radiometer footprint model to estimate sunlit and shaded components for row crops. Agron. J., 102(3), 942-955. http://dx.doi.org/10.2134/agronj2009.0393.

Colaizzi, P. D., Evett, S. R., Howell, T. A., Gowda, P. H., O’Shaughnessy, S. A., Tolk, J. A., Kustas, W. P., \& Anderson, M. C. (2012a). Two-source energy balance model-refinements and lysimeter tests in the Southern High Plains. Trans. ASABE, 55(2), 551-562. http://dx.doi.org/10.13031/2013.41385.

Colaizzi, P. D., Kustas, W. P., Anderson, M. C., Agam, N., Tolk, J. A., Evett, S. R., Howell, T. A., Gowda, P. H., \& O'Shaughnessy, S. A. (2012b). Two-source energy balance model estimates of evapotranspiration using component and composite surface temperatures. Adv. Water Res., 50, 134-151. http://dx.doi.org/10.1016/j.advwatres.2012.06.004.

Colaizzi, P. D., Evett, S. R., Howell, T. A., Li, F., Kustas, W. P., \& Anderson, M. C. (2012c). Radiation model for row crops: I. Geometric model description and parameter optimization. Agron. J., 104(2), 225-240. http://dx.doi.org/10.2134/agronj2011.0082.

Colaizzi, P. D., Schwartz, R. C., Evett, S. R., Howell, T. A., Gowda, P. H., \& Tolk, J. A. (2012d). Radiation model for row crops: II. Model evaluation. Agron. J., 104(2), 241-255. http://dx.doi.org/10.2134/agronj2011.0083.

Crago, R. D. (1996). Conservation and variability of the evaporative fraction during the daytime. J. Hydrol., 180(1-4), 173-194. 
http://dx.doi.org/10.1016/0022-1694(95)02903-6.

Doorenbos, J., \& Kassam, A. H. (1979). Yield response to water. Irrigation and Drainage Paper No. 33. Rome, Italy: United Nations FAO.

Evett, S. (1989). Field investigations of evaporation from a bare soil. PhD diss. Tucson, Ariz.: University of Arizona, Department of Soil and Water Science.

Evett, S. R. (2002). Water and energy balances at soil-plantatmosphere interfaces. In A. A. Warrick (Ed.), The Soil Physics Companion (pp. 127-188). Boca Raton, Fla.: CRC Press.

Evett, S. R., \& Tolk, J. A. (2009). Introduction: Can water use efficiency be modeled well enough to impact crop management? Agron J., 101(3), 423-425. http://dx.doi.org/10.2134/agronj2009.0038xs.

Evett, S., Matthias, A., \& Warrick, A. (1994). Energy balance model of spatially variable evaporation from bare soil. SSSA J., 58(6), 1604-1611.

http://dx.doi.org/10.2136/sssaj1994.03615995005800060003x.

Evett, S. R., Warrick, A., \& Matthias, A. (1995). Wall material and capping effects on microlysimeter temperatures and evaporation. SSSA J., 59(2), 329-336.

Evett, S. R., Kustas, W. P., Gowda, P. H., Anderson, M. C., Prueger, J. H., \& Howell, T. A. (2012a). Overview of the Bushland evapotranspiration and remote sensing experiment 2008 (BEAREX'08): A field experiment evaluating methods for quantifying ET at multiple scales. Adv. Water Resources, 50, 419. http://dx.doi.org/10.1016/j.advwatres.2012.03.010.

Evett, S., Schwartz, R. C., Howell, T. A., Baumhardt, R. L., \& Copeland, K. S. (2012b). Can weighing lysimeter ET represent surrounding field ET well enough to test flux station measurements of daily and sub-daily ET? Weighing lysimeter and neutron probe water balance methods of determining crop water use in BEAREX'08. Adv. Water Resources, 50, 79-90. http://dx.doi.org/10.1016/j.advwatres.2012.07.023.

French, A. N., Hunsaker, D. J., Clarke, T. R., Fitzgerald, G. J., Luckett, W. E., \& Pinter Jr., P. J. (2007). Energy balance estimation of evapotranspiration for wheat grown under variable management practices in central Arizona. Trans. ASABE, 50(6), 2059-2071. http://dx.doi.org/10.13031/2013.24108.

Guzinski, R., Anderson, M. C., Kustas, W. P., Nieto, H., \& Sandholt, I. (2013). Using a thermal-based two-source energy balance model with time-differencing to estimate surface energy fluxes with day-night MODIS observations. Hydrol. Earth Syst. Sci., 17(7), 2809-2825. http://dx.doi.org/10.5194/hess-17-28092013.

Howell, T. A., Schneider, A. D., Dusek, D. A., Marek, T. H., \& Steiner, J. L. (1995). Calibration and scale performance of Bushland weighing lysimeters. Trans. ASAE, 38(4), 1019-1024. http://dx.doi.org/10.13031/2013.27918.

Idso, S. B. (1981). A set of equations for full spectrum and 8 to 14 $\mu \mathrm{m}$ and 10.5 to $12.5 \mu \mathrm{m}$ thermal radiation from cloudless skies. Water Resources Res., 17(2), 295-304. http://dx.doi.org/10.1029/WR017i002p00295.

Idso, S. B., Jackson, R. D., Ehrler, W. L., \& Mitchell, S. T. (1969). A method for determination of infrared emittance of leaves. Ecol., 50(5), 899-902. http://dx.doi.org/10.2307/1933705.

Idso, S. B., Reginato, R. J., \& Farah, S. M. (1982). Soil- and atmosphere-induced plant water stress in cotton as inferred from foliage temperatures. Water Resources Res., 18(4), 1143-1148. http://dx.doi.org/10.1029/WR018i004p01143.

Irmak, S., Howell, T. A., Allen, R. G., Payero, J. O., \& Martin, D. L. (2005). Standardized ASCE Penman-Monteith: Impact of sum-of-hourly vs. 24-hour timestep computations at reference weather station sites. Trans. ASAE, 48(3), 1063-1077. http://dx.doi.org/10.13031/2013.18517.

Jackson, R. D. (1982). Canopy temperature and crop water stress. In
D. Hillel (Ed.), Advances in Irrigation (Vol. 1, pp. 43-85). New York, N.Y.: Academic Press.

Jackson, R. D., Idso, S. B., Reginato, R. J., \& Pinter, P. J. (1981). Canopy temperature as a crop water stress indicator. Water Resources Res., 17(4), 1133-1138. http://dx.doi.org/10.1029/WR017i004p01133.

Jackson, R. D., Hatfield, J. L., Reginato, R. J., Idso, S. B., \& Pinter Jr., P. J. (1983). Estimation of daily evapotranspiration from one-time-of-day measurements. Agric. Water Mgmt., 7(3), 351362. http://dx.doi.org/10.1016/0378-3774(83)90095-1.

Jury, W. A., \& Tanner, C. B. (1975). Advection modification of the Priestley and Taylor evapotranspiration formula. Agron. J., 67(6), 840-842. http://dx.doi.org/10.2134/agronj1975.00021962006700060031x.

Kalma, J. D., McVicar, T. R., \& McCabe, M. F. (2008.). Estimating land surface evaporation: A review of methods using remotely sensed surface temperature data. Surveys in Geophysics, 29(4-5), 421-469. http://dx.doi.org/10.1007/s10712-008-9037-z.

Kustas, W. P., \& Anderson, M. C. (2009). Advances in thermal infrared remote sensing for land surface modeling. Agric. Forest Meteorol., 149(12), 2071-2081. http://dx.doi.org/10.1016/j.agrformet.2009.05.016.

Kustas, W. P., \& Norman, J. M. (1999). Evaluation of soil and vegetation heat flux predictions using a simple two-source model with radiometric temperatures for partial canopy cover. Agric. Forest Meteorol., 94(1), 13-29. http://dx.doi.org/10.1016/S0168-1923(99)00005-2.

Kustas, W. P., Alfieri, J. G., Anderson, M. C., Colaizzi, P. D., Prueger, J. H., Evett, S. R., French, A. N., Copeland, K. S., Howell, T. A., Neal, C. M., Hipps, L. E., \& Chavez, J. L. (2012). Evaluating the two-source energy balance model using local thermal and surface flux observations in a strongly advective irrigated agricultural area. Adv. Water Resources, 50, 120-133. $\mathrm{http} / / / \mathrm{dx}$.doi.org/10.1016/j.advwatres.2012.07.005.

Legates, D. R., \& McCabe Jr., G. J. (1999). Evaluating the use of "goodness-of-fit" measures in hydrologic and hydroclimatic model validation. Water Resources Res., 35(1), 233-241. http://dx.doi.org/10.1029/1998WR900018.

Li, F., Kustas, W. P., Prueger, J. H., Neal, C. M., \& Jackson, T. J. (2005). Utility of remote sensing-based two-source energy balance model under low- and high-vegetation cover conditions. J. Hydrometeorol., 6(6), 878-891. http://dx.doi.org/10.1175/JHM464.1.

Li, Z., Tang, R., Wan, Z., Bi, Y., Zhou, C., Tang, B., Yan, G., \& Zhang, X. (2009). A review of current methodologies for regional evapotranspiration estimation from remotely sensed data. Sensors, 9(5), 3801-3853. http://dx.doi.org/10.3390/s90503801.

Liu, G., Liu, Y., Hafeez, M., Xu, D., \& Vote, C. (2012). Comparison of two methods to derive time series of actual evapotranspiration using eddy covariance measurements in the southeastern Australia. J. Hydrol., 454-455, 1-6. http://dx.doi.org/10.1016/j.jhydrol.2012.05.011.

Marek, T. H., Schneider, A. D., Howell, T. A., \& Ebeling, L. L. (1988). Design and construction of large weighing monolithic lysimeters. Trans. ASAE, 31(2), 477-484.

Newman, B. D., Wilcox, B. P., Archer, S. R., Breshears, D. D., Dahm, C. N., Duffy, C. J., McDowell, N. G., Phillips, F. M., Scanlon, B. R., \&Vivoni, E. R. (2006). Ecohydrology of waterlimited environments: A scientific vision. Water Resources Res., 42(6), W06302. http://dx.doi.org/10.1029/2005WR004141.

Norman, J. M., \& Becke, F. (1995). Terminology in thermal infrared remote sensing of natural surfaces. Remote Sensing Rev., 12(3-4), 159-173. http://dx.doi.org/10.1080/02757259509532284.

Norman, J. M., Kustas, W. P., \& Humes, K. S. (1995). Source 
approach for estimating soil and vegetation energy fluxes in observations of directional radiometric surface temperature. Agric. Forest Meteorol., 77(3-4), 263-293. http://dx.doi.org/10.1016/0168-1923(95)02265-Y.

Norman, J. M., Kustas, W. P., Prueger, J. H., \& Diak, G. H. (2000). Surface flux estimation using radiometric temperature: A dual temperature-difference method to minimize measurement errors. Water Resources Res., 36(88), 2263-2274. http://dx.doi.org/10.1029/2000WR900033.

O’Shaughnessy, S., Evett, S. R., Colaizzi, P. D., \& Howell, T. A. (2011). Using radiation thermography and thermometry to evaluate crop water stress in soybean and cotton. Agric. Water Mgmt., 98(10), 1523-1535. http://dx.doi.org/10.1016/j.agwat.2011.05.005.

O'Shaughnessy, S., Evett, S. R., Colaizzi, P. D., \& Howell, T. A. (2012). A crop water stress index and time threshold for automatic irrigation scheduling of grain sorghum. Agric. Water Mgmt., 107, 122-132. http://dx.doi.org/10.1016/j.agwat.2012.01.018.

Peters, R., \& Evett, S. (2004). Modeling diurnal canopy temperature dynamics using one-time-of-day measurements and a reference temperature curve. Agron. J., 96(6), 1553-1561. http://dx.doi.org/10.2134/agronj2004.1553.

Peters, R., \& Evett, S. (2008). Automation of a center pivot using the temperature-time-threshold method of irrigation scheduling. J. Irrig. Drainage, 134(3), 286-291. http://dx.doi.org/10.1061/(ASCE)0733-9437(2008)134:3(286).

Priestley, R., \& Taylor, R. (1972). On the assessment of surface heat flux and evaporation using large-scale parameters. Monthly Weather Rev., 100(2), 81-92. http://dx.doi.org/10.1175/15200493(1972) $100<0081$ :OTAOSH $>2.3 . C O ; 2$.

Santanello Jr., J. A., \& Friedl, M. A. (2003). Diurnal covariation in soil heat flux and net radiation. J. Appl. Meteorol., 42(6), 851862. http://dx.doi.org/10.1175/15200450(2003)042<0851:DCISHF $>2.0$. CO;2.

Schneider, A. D., \& Howell, T. A. (2000). Surface runoff due to
LEPA and spray irrigation of a slowly permeable soil. Trans ASAE, 43(5), 1089-1095. http://dx.doi.org/10.13031/2013.3001.

Steiner, J. L., Howell, T. A., \& Schneider, A. D. (1991). Lysimetric evaluation of daily potential evapotranspiration models for grain sorghum. Agron. J., 83(1), 240-247. http://dx.doi.org/10.2134/agronj1991.00021962008300010055x.

Tolk, J. A., Evett, S. R., \& Howell, T. A. (2006a). Advection influences on evapotranspiration of alfalfa in a semiarid climate. Agron. J., 98(6), 1646-1654. http://dx.doi.org/10.2134/agronj2006.0031.

Tolk, J. A., Howell, T. A., \& Evett, S. R. (2006b). Nighttime evapotranspiration from alfalfa and cotton in a semiarid climate. Agron. J., 98(3), 730-736. http://dx.doi.org/10.2134/agronj2005.0276.

USDA-NRCS. (2013). Soil Survey TX375: Potter County, Texas. Washington, D.C.: USDA Natural Resources Conservation Service. Retrieved from http://websoilsurvey.nrcs.usda.gov.

Van Niel, T. G., McVicar, T. R., Roderick, M. L., van Dijk, A. I., Renzullo, L. J., \& van Gorsel, E. (2011). Correcting for systematic error in satellite-derived latent heat flux due to assumptions in temporal scaling: Assessment from flux tower observations. J. Hydrol., 409(1-2), 140-148. http://dx.doi.org/10.1016/j.jhydrol.2011.08.011.

Van Niel, T. G., McVicar, T. R., Roderick, M. L., van Dijk, A. I., Beringer, J., Hutley, L. B., \& van Gorsel, E. (2012). Upscaling latent heat flux for thermal remote sensing studies: Comparison of alternative approaches and correction of bias. J. Hydrol., 468469, 35-46. http://dx.doi.org/10.1016/j.jhydrol.2012.08.005.

Wanjura, D. F., \& Upchurch, D. R. (1996). Time thresholds for canopy temperature-based irrigation. In Proc. Intl. Conf. Evapotranspiration and Irrigation Scheduling (pp. 295-303). St. Joseph, Mich.: ASAE.

Wanjura, D. F., Maas, S. J., Winslow, J. C., \& Upchurch, D. R. (2004). Scanned and spot-measured canopy temperatures of cotton and corn. Computers Elect. Agric., 44(1), 33-48. http://dx.doi.org/10.1016/j.compag.2004.02.005. 